\title{
FOR GOODNESS' SAKE: \\ A TWO-PART PROPOSAL FOR REMEDYING THE UNITED STATES CHARITY/JUSTICE IMBALANCE \\ Fran Quigley *
}

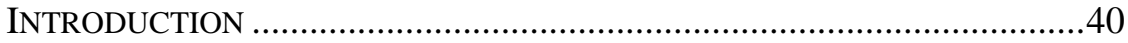

I. CHARITY AS MORAL SAFETY VALVE ...................................45

II. ELIMINATE THE U.S. CHARITABLE TAX DEDUCTION .........50

A. An Inequitable Reward for the Wealthy ...................................50

B. Exposing the Charity Illusion....................................................55

III. U.S. RATIFICATION OF THE INTERNATIONAL COVENANT ON ECONOMIC, SOCIAL AND

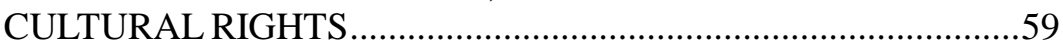

A. History of Economic and Social Rights...................................60

B. The International Covenant on Economic, Social and

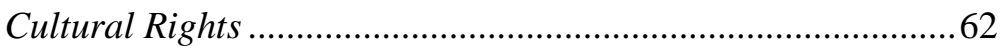

C. The United States and Economic and Social Rights.................66

D. Arguments Against U.S. Ratification of the ICESCR..................70

1. Economic and social rights are contrary to the law and character of the U.S......................................................70

2. Economic and social rights are inferior to civil and

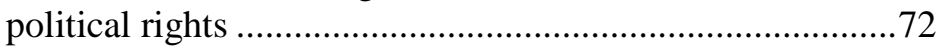

3. Economic and social rights are not justiciable.....................74

E. Arguments for U.S. Ratification of the International

Covenant on Economic, Social and Cultural Rights .................. 76

1. Ratification of the ICESCR would lead to improved economic and social conditions for the U.S.

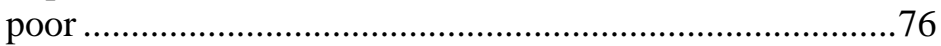

2. Economic and Social Rights are Justiciable in the United States ....

F. The U.S. Post-Ratification of the ICESCR …............................... 85 CONCLUSION

Clinical Professor, Indiana University McKinney School of Law. The author thanks Florence Wagman Roisman, Bill Quigley, Janet Poppendieck, and George Wright for their valuable comments on earlier drafts of this article. 


\section{FOR GOODNESS' SAKE: \\ A TWO-PART PROPOSAL FOR REMEDYING THE UNITED STATES CHARITY/JUSTICE IMBALANCE}

\section{Fran Quigley}

The approach to addressing economic and social needs in the United States strongly favors individual and corporate charity over the establishment and enforcement of economic and social rights. This charity/justice imbalance has a severely negative impact on the nation's poor, who struggle with inadequate access to healthcare, housing, and nutrition, despite high overall U.S. wealth. This article suggests a two-part approach for remedying the charity/justice imbalance in the United States. First, the U.S. should eliminate the charitable tax deduction, a policy that does not effectively address economic and social needs, forces an inequitable poverty relief and tax burden on the middle class, and lulls the nation into a false sense of complacency about its poverty crisis. Second, the U.S. should replace the deduction with ratification of the International Covenant on Economic, Social and Cultural Rights. This twopart process would reverse the U.S. legacy of avoiding enforceable commitments to economic and social rights. Charity would take a step back and justice a step forward.

\section{INTRODUCTION}

$\mathrm{W}$ HEN I worked for our local legal services program here in Indiana, we often represented clients who had profound disabilities or severe illnesses, but were unable to obtain the medicine and care they had been prescribed. ${ }^{1}$ Our state government provides very limited access to the health insurance program Medicaid, so these clients' applications were routinely rejected.

Once, when one of my colleagues helped a client file an appeal of such a decision, he groaned when the case was assigned to a judge who was known for his outspoken contempt of "welfare.” The judge listened to a full hour of evidence about the woman's chronic pain and struggles to afford medication and therapy. Then, he promptly denied her request for Medicaid coverage. The woman left the courtroom in tears.

Her lawyer started packing up his files to leave as well. The judge lingered for a moment, and broke from his stoic demeanor. "It really is too bad what she is going through," he said to my colleague. "Isn't there some kind of program out there to help people like her?”

\footnotetext{
${ }^{1}$ Portions of this article were originally published in Fran Quigley, The Limits of Philanthropy: Time to Eliminate the Charitable Tax Deduction, CommonweAL (Jan. 8, 2015),https://www.commonwealmagazine.org/limits-philanthropy?utm_content= buffere963d\&utm_medium=social\&utm_source=twitter.com\&utm_campacign=buffer.
} 
The judge meant a charity program, and the answer is no. The woman was in need of expensive healthcare, not to mention housing and food, and her needs were likely to be permanent. Every free clinic director or homeless shelter staffer I have ever known would tell the judge that their efforts are no substitute for a reliable social safety net, or living wage employment, but that judge is just one of many people who disfavor such government programs. ${ }^{2}$ Instead, they possess a comforting belief in a mythical "program out there," a charity that will bridge the gap between grinding poverty and a safe, healthy existence. ${ }^{3}$

This view on the effectiveness of charitable programs is a peculiarly American one. Compared to the U.S., other developed countries devote far more government funds to meet social needs. The U.S. spends about $20 \%$ of its gross domestic product on government assistance with essentials like healthcare, food, and housing. ${ }^{4}$ Most other democratic, marketbased countries spend significantly more. Germany, for example, spends $25 \%$ of its GDP on government-provided assistance; the United Kingdom almost $24 \%{ }^{5}$

Over the past seventy years, the global community has embraced the idea of the human right to basic life necessities. The Universal Declaration of Human Rights, adopted in 1948, strongly affirms each individual's entitlement to food, medical care, and an adequate standard of living. ${ }^{6}$ The International Covenant on Economic, Social and Cultural Rights ("ICESR") followed, creating enforceable rights out of the Uni-

\footnotetext{
${ }^{2}$ Many Americans hold a view that government welfare programs actually increase U.S. poverty. See Erin McClam, Many Americans Blame 'Government Welfare' for Persistent Poverty, Poll Finds, NBC NEWS (June 6, 2013, 2:18 PM), http://www.nbcnews.com/feature/in-plain-sight/many-americans-blame-governmentwelfare-persistent-poverty-poll-finds-v18802216 (When provided a list of eight factors and asked to choose the one most responsible for the continuing problem of poverty, the factor that was chosen by 24 percent of respondents, the highest total of all factors, was "too much government welfare that prevents initiative."); see also Jeffrey M. Jones, Americans Say Federal Gov't Wastes Over Half of Every Dollar, GalluP, (Sept. 19, 2011),http://www.gallup.com/poll/149543/americans-say-federal-gov-wastes-half-everydollar.aspx ("Americans have become increasingly likely to see all levels of government as being wasteful of tax dollars.”).

${ }^{3}$ Three-Fourths of Americans Favor Charitable Tax Deduction: Survey Indicates Any Changes to System Would Face Strong Opposition, Dunham \& Co. (Feb. 7, 2012), http://dunhamandcompany.com/2012/02/three-fourths-of-americans-favor-charitabletax-deduction/ (reporting survey results of $73 \%$ of Americans believing that private nonprofits are better than the government at promoting the social good).

${ }^{4}$ Organisation for ECONOMic Co-Operation and Development, OECD FACtBook 2014: Economic, Environmental And Social Statistics (2014), http://www.oecd-ilibrary.org/sites/factbook-2014-90-en/index.html?content Type=\&itemId=\%2fcontent\%2fchapter\%2ffactbook-2014-90-en\&mimeType= text\%2fhtml\&containerItemId=\%2fcontent\%2fserial\%2f18147364\&accessItemIds=

${ }^{5} I d$.

${ }^{6}$ Universal Declaration of Human Rights, G.A. Res. 217 (III) A, U.N. Doc. A/RES/217(III), at art. 25 (Dec. 10, 1948).
} 
versal Declaration's statements of principle. ${ }^{7}$ But the notion of those socalled "positive" rights, which call on the government to take action for economic and social welfare, has not taken root in the U.S. ${ }^{8}$ Americans cherish their constitutionally protected "negative" rights, the ones that protect against government interference in speech, religious expression, and privacy. ${ }^{9}$ But, compared to other industrialized democracies, the U.S. is resistant to social entitlements. ${ }^{10}$ The majority of the world's countries, including every other western industrialized nation, has agreed to the ICESCR. ${ }^{11}$ The United States has refused to ratify it. ${ }^{12}$

It is not that Americans are hard-hearted. In contrast to the country's relative stinginess in spending government resources on social needs, its citizens have been singled out for being more charitable than their counterparts in similar nations. ${ }^{13}$ On average, Americans donate nearly $2 \%$ of their overall income to nonprofit organizations, ${ }^{14}$ and over $80 \%$ of U.S. households report making such gifts. ${ }^{15}$ As a result, nonprofits are a big part of the U.S. culture and economy. Not only does the United States count on them to meet many social needs that in other countries are provided by the state, nonprofit organizations employ one in every ten members of the U.S. workforce. ${ }^{16}$

${ }^{7}$ G.A. Res. 2200A, at 49, U.N. GAOR, 21st Sess., Supp. No. 16, U.N. Doc. A/6316 (1966).

${ }^{8}$ See Isaiah Berlin, Two Concepts of Liberty, in Four EssAys on LiBerTy (1969). The philosopher Isaiah Berlin articulated a difference between civil and political rights, which block the government from taking certain actions against individuals, and economic, social and cultural rights, which require government action, as a contrast between positive and negative liberties. Others have since pointed out that the difference between the two categories of rights is often overstated; see infra note 265.

9 See, e.g., Aryeh Neier, The International Human Rights Movement: A HistORY, 62-86 (2012) (discussing the nature of rights).

${ }^{10}$ But see infra note 138 for discussion of economic and social entitlements created by U.S. legislative and state constitutional mandates.

${ }^{11}$ United Nations Office of the High Commissioner of Human Rights, Status of Ratifications of ICESCR, https://treaties.un.org/Pages/ViewDetails.aspx? src=TREATY\&mtdsg_no=IV-3\&chapter=4\&lang=en.

${ }^{12} I d$.

13 See Charities AND Foundation, World Giving Index 2014 (Nov., 2014),https://www.cafonline.org/docs/default-source/about-us-publications/ caf_wgi2014_report_1555awebfinal.pdf (“The U.S is the only country to rank in the Top 10 for all three kinds of giving covered by the World Giving Index: helping a stranger (1st), volunteering time (joint 5th) and donating money (9th).”).

${ }^{14}$ Suzanne Perry, The Stubborn 2\% Giving Rate: Even As More Fundraisers Seek Donations, Americans Don't Dig Deeper, The Chron. of Philanthropy, (June 17, 2013), http://philanthropy.com/article/The-Stubborn-2-Giving-Rate/139811/.

${ }^{15}$ Most Americans Practice Charitable Giving, Volunteerism, GALLUP (Dec. 13, 2013), http://www.gallup.com/poll/166250/americans-practice-charitable-givingvolunteerism.aspx.

${ }^{16}$ Center for Civil Society, Holding the Fort: NonProfit EMPloyment DURING A DECADE OF TURMOIL 3 (2012), http://ccss.jhu.edu/wp-content/uploads/ downloads/2012/01/NED_National_2012.pdf. 
The prominent role that individual charity plays in the United States is both enduring and celebrated. Famously, Alexis de Tocqueville swooned over the early $19^{\text {th }}$ century American predilection for forming voluntary organizations. ${ }^{17}$ In the years since, the country has created a market-oriented system of providing services via thousands of individual charities funded by discretionary donations. ${ }^{18}$ Americans get to vote with their wallets on what kind of support they wish to provide for the poor, an arrangement that has proven to be a good fit for the individualistic culture of the United States. ${ }^{19}$ Applause for charity and volunteerism is a staple of U.S. political rhetoric across the ideological spectrum. President George H. W. Bush had his "Thousand Points of Light;" 20 President Barack Obama promotes “United We Serve.”21 In 1981, President Ronald Reagan explicitly justified a cut in government social spending by appealing to American's preference for voluntary charity:

The truth is that we've let Government take away many things we once considered were really ours to do voluntarily out of the goodness of our hearts and a sense of

${ }^{17}$ Alexis de Toqueville, Democracy in America 595 (Arthur Goldhammer trans., 2012) (1835) ("The Americans make associations to give entertainments, to found seminaries, to build inns, to construct churches, to diffuse books, to send missionaries to the antipodes; in this manner they found hospitals, prisons, and schools. If it is proposed to inculcate some truth or to foster some feeling by the encouragement of a great example, they form a society ... I have often admired the extreme skill with which the inhabitants of the United States succeed in proposing a common object for the exertions of a great many men and in inducing them voluntarily to pursue it.”).

${ }^{18}$ See Frequently Asked Questions, NATIONAL Center for Chartiable Statistics, http://nccs.urban.org/FAQ/ (In 2012, more than 1.4 million exempt organizations had formally obtained recognition of their tax-exempt status from the Internal Revenue Service.).

${ }^{19}$ See Stephen L. Carter, Ending Charity Tax Break Will Hurt Poor Most, BLOOMBERG (Nov. 22, 2011), http://www.bloomberg.com/news/2011-11-23/ending-charity-tax-break-would-hurtpoor-commentary-by-stephen-l-carter.html ("[T]he individual who gives to charity might measure the needs of the community by different calipers than centralized policy makers, and will therefore contribute to a different set of causes ... These millions of individual decisions lead to a diversity in spending that would be impossible if we adopted the theory that the only money spent for the public good is the money spent by the state.”).

20 See How Volunteering Became a Movement, POINTS OF Light, http://www.pointsoflight.org/about-us ("Cast from the vision of 1,000 points of light shared by our founder President George H. W. Bush in his 1989 inaugural address, today Points of Light transcends politics and borders to inspire millions of volunteers worldwide.").

${ }^{21}$ About United We Serve, UnITED WE SERVE, http://www.serve.gov/?q=sitepage/about-united-we-serve ("This initiative aims to both expand the impact of existing organizations by engaging new volunteers in their work and encourage volunteers to develop their own 'do-it-yourself' projects.”). 
community pride. I believe many of you want to do those things again .... ${ }^{22}$

But, for the American poor, there is a problem: this myth is no match for reality. Popular confidence in the efficacy of charitable approaches is not supported by the evidence. Private nonprofit programs addressing economic and social needs suffer from insufficient resources, many employ non-professional approaches to providing services, and the sector's work often reflects the wishes of wealthy donors rather than community needs. ${ }^{23}$ Despite the country's overall wealth, the United States has higher poverty rates ${ }^{24}$ and income inequality ${ }^{25}$ than comparable countries. Those numbers translate to widespread suffering, evidenced by millions lacking access to healthcare ${ }^{26}$ and safe, affordable housing. ${ }^{27}$ The scattershot U.S. charitable efforts translate to a proliferation of soup kitchens and short-term homeless shelters, while sustainable nutrition assistance, healthcare, and housing support is scarce. ${ }^{28}$

\footnotetext{
${ }^{22}$ Ronald Reagan, Address to the Nation on the Program for Economic Recovery (Sept. 24, 1981), http://www.reagan.utexas.edu/archives/speeches/ 1981/92481d.htm.

${ }^{23}$ See Lester Salamon, Of Market Failure, Voluntary Failure, and Third-Party Gov-
} ernment: Toward a Theory of Government-Nonprofit Relations in the Modern Welfare State, 16 J. Voluntary Action Res. 29 (1987) (outlining a four-part critique of philanthropic approaches on the basis of the sector's insufficiency, paternalism, particularism, and amateurism).

${ }^{24}$ Elise Gould \& Hilary Wething, Economic Policy Institute, U.S. Poverty Rates Higher, Safety Net Weaker Than In Peer Countries 2-4 (July 24, 2012), http://www.epi.org/publication/ib339-us-poverty-higher-safety-net-weaker/.

${ }^{25}$ Oliver Denk et al., Organization For Economic Co-Operation And Development, Inequality And Poverty In The United States 13 (May 27, 2013), http://www.oecdilibrary.org/economics/inequality-and-poverty-in-the-united-states_5k46957cwv8q-en.

${ }^{26}$ See Kaiser Family Foundation, Key Facts About The Uninsured Population, KAISER FAMILY Foundation (Oct. 29, 2014), http://kff.org/uninsured/fact-sheet/keyfacts-about-the-uninsured-population/ (noting that 41 million Americans lacked health insurance in 2013, although the implementation of the Affordable Care Act caused the uninsured rate to drop for nonelderly individuals in the first quarter of 2014 by a full percentage point relative to the first quarter of the previous year.). Predictably, the poor in the U.S. also have significantly worse health outcomes than counterparts with higher incomes. See Commonwealth Fund Health Care In The Two Americas: Findings From The Scorecard On State Health System Performance For Low-Income Populations (2013) (Sept. 18, 2013), http://www.commonwealthfund.org/ publications/fund-reports/2013/sep/low-income-scorecard ("Lower-income populations are at increased risk of experiencing worse access, lower-quality care-particularly in outpatient settings - and worse health outcomes compared to those with higher incomes in their home state. Income-related disparities were most pronounced on measures of access, prevention, potentially unsafe prescription medication, and health outcomes.”).

27 National Low-Income Housing Coalition, Out Of Reach 4 (2014), http://nlihc.org/oor/2014 (noting unmet need for 7 million housing units for extremely low-income Americans).

${ }^{28}$ Id.; see also FOOD RESEARCh ACTION COUnCIL, FoOd HARDShip In AMERICA 2012 (Feb. 2013), http://frac.org/pdf/food_hardship_2012.pdf (noting that more than one in six Americans report inability to afford enough food.). 
Many commentators have bemoaned the U.S. imbalance between charity and justice for the poor. ${ }^{29}$ But, like the proverbial complaints about the weather, the problem is identified far more often than solutions are posed. This article urges a two-part approach to remedying the charity/justice imbalance in the United States. First, the United States should eliminate the charitable tax deduction. It is a policy that does not effectively address economic and social needs, it forces an inequitable poverty relief and tax burden on the middle class, and it lulls the nation into a false sense of complacency about its poverty crisis. Second, the United States should replace the deduction, an artifact of the charity model, by ratifying the International Covenant on Economic, Social and Cultural Rights. Ratification would be a step toward reversing the American legacy of avoiding an enforceable commitment to economic and social justice.

\section{CHARITY AS MORAL SAFETY VALVE}

The principle that charity is no substitute for justice substantially predates the $20^{\text {th }}$ century human rights movement. People of faith can point to ancient religious traditions as the source for a mandate that all humans deserve justice, which includes enforceable rights to basic necessities. Old Testament prophets in particular spoke in terms of justice, with Micah and Amos trying to shake up the complacency of the pious, yet economically stratified $8^{\text {th }}$ century B.C.E. Israel. ${ }^{30}$ In God's name, they issued impassioned commands to, in Amos' words, "let justice roll down like waters, and righteousness like an ever-flowing stream.” 31 Isaiah's mandate to "loose the bonds of wickedness" 32 was the passage that Jesus chose to read to those gathered in the synagogue in the Gospel of Luke. ${ }^{33}$

The Quran speaks passionately of justice, ${ }^{34}$ and Confucian principles embrace a community-wide obligation to provide for the needs of all. ${ }^{35}$

\footnotetext{
${ }^{29}$ See Mike Konczal, The Voluntarism Fantasy, DEMOCRACY: A Journal Of IDEAS (Spring, 2014), http://www.democracyjournal.org/32/the-voluntarismfantasy.php?page=all ("The last 30 years have seen effort after effort to try and push the policy agenda away from the state's capabilities and toward private mechanisms for mitigating the risks we face in the world. This effort is exhausted, and future endeavors will require a greater, not lesser, role for the public.”).

30 J, Kenneth Kurtz, The People Of Ancient IsRael 257 (2009) (“"In the $9^{\text {th }}$ century B.C.][a]s one decade followed another, the contrasts between rich and poor became even more pronounced in Israel. In the ninth century, the social abuses and sharp economic distinctions of an increasingly stratified society had been of little concern to the monarchy, and by the middle of the eight century such problems were met with complete indifference.”).

${ }^{31}$ Amos 5:24 (English Standard Version).

${ }^{32}$ Isaiah 58:6 (English Standard Version).

${ }^{33}$ Luke 4:16-18 (English Standard Version).

${ }^{34}$ Qur'an 16:90 (Saheeh International Version) ("Indeed, Allah orders justice and good conduct and giving to relatives and forbids immorality and bad conduct and oppression.”).
} 
St. Augustine said that charity cannot make up for justice withheld. ${ }^{36}$ Evangelical Christian and Sojourners magazine founder Jim Wallis is one of many faith leaders who explains the charity/justice conflict in terms of the parable of babies in the river. ${ }^{37}$ If a series of babies are found floating down the river, the community can respond by pulling each one out and caring for them. It would be a pure act of admirable charity, repeated over and over. But it is also incumbent on members of that community to go upstream to remedy the injustice that is causing those babies to be cast into the river in the first place. ${ }^{38}$ "All our religious and spiritual traditions focus on how we treat materially poor and excluded people, and suggest that the state of poor people is a moral test for the health of any society," Wallis says. "And those traditions point us beyond mere charity as a response, but call us more prophetically to the deeper solutions of social and economic justice.”39

Modern-day faith leaders have echoed similar messages. "Where are the saints to try to change the social order; not just to minister to the slaves but to do away with slavery?” asked $20^{\text {th }}$ century Catholic activist Dorothy Day. ${ }^{40}$ A succession of Popes has insisted that Catholics pursue a just social order that makes charity less necessary. ${ }^{41}$ Even the conserv-

35 Joseph Chan, Making Sense of Confucian Justice, POLYlog: Forum For InTERCUltural PHILOSOPHY 3 (2001), http://them.polylog.org/3/fcj-en.htm (“A just society therefore has the following features: 1 ) Sufficiency for all - there is state provision to ensure that each citizen enjoys a level of material goods sufficient to live a good life. First priority would be given to the poor and needy."). See also MARY ANN Glendon, A World Made New: Eleanor Roosevelt And The Universal Declaration Of Human Rights 185 (2002) (quoting Peng-chun Chang 1946 speech to Economic and Social Council in support of economic and social rights: "Provisions are made for the aged, employment is provided for the able-bodied and education is afforded to the young. Widows and widowers, orphans and the childless, the deformed and the diseased, all are cared for.").

36 Augustine of Hippo Quotes, The European Graduate School, http://www.egs.edu/library/augustine-of-hippo/quotes/.

${ }^{37}$ See Sarah Van Gelder, Meet the Refreshing Evangelical Who's Leading a Revival-of "the Common Good," Yes MAGAzINE (May 30, 2013), http://www.yesmagazine.org/issues/love-and-the-apocalypse/jim-wallis-the-commongood-in-a-violent-world.

${ }^{38} \mathrm{Id}$. ("Too many people are hauling drowning people out of the river-which is a good thing to do-but not sending somebody upstream to find out who or what's throwing them in. A lot of people are still trying to work with the symptoms and the victimswhich is wonderful and compassionate-but now we need to look at the causes.”).

${ }^{39}$ John Asling, Moving from Charity Towards Justice in Outreach Ministries, HAMILTON CONFERENCE http://www.hamconf.org/TW_Charity.pdf.

${ }^{40}$ Robert Ellsberg, Dorothy Day: Lecture on Centenary, THE CATHOLIC WoRKeR Movement (November 8, 1997), http://www.catholicworker.org/dorothyday/ canonizationtext.cfm?Number=33.

${ }^{41}$ See, e.g., Pope Leo XiII, Encyclical Letter Rerum Novarum (1891) (Pope Leo XIII cites the teachings of Thomas Aquinas, saying that capitalism's rough edges have to be smoothed out by the state guaranteeing workers a living wage: "[There is] a dictate of natural justice more imperious and ancient than any bargain between man and man, namely, that wages ought not to be insufficient to support a frugal and wellbehaved wage-earner.”); PoPE PIUS XI, PIUS XI, ENCYCLICAL 
ative Pope Benedict XVI said in 2005, "Instead of contributing through individual works of charity to maintaining the status quo, we need to build a just social order in which all receive their share of the world's goods and no longer have to depend on charity." 42 The Rev. William Sloane Coffin explained the need for enforceable rights: "Human nature is sinful, and therefore the virtue of the few will never compensate for the inertia of the many," wrote the minister, peace activist, and chaplain at Yale University. "Given human goodness, voluntary contributions are possible, but given human sinfulness, legislation is indispensable. Charity, yes always; but never as a substitute for justice."43

Generations of philosophers have made the same argument from a secular perspective. Immanuel Kant wrote, "In giving to an unfortunate man, we do not give him a gratuity but only help to return to him that of which the general injustice of our system has deprived him.”" ${ }^{44}$ Brazilian educator Paolo Friere said that true generosity is expressed by fighting to destroy the need for charity. ${ }^{45}$ Noted $21^{\text {st }}$ century ethicist Allen Buchanan outlines a continuum running from charity to justice, with moral progress occurring when the realm of justice expands into what was previously considered to be the domain of charity. ${ }^{46}$ Writers and political leaders have delivered similar pronouncements. Samuel Johnson found the world to be kinder than he expected but less just ${ }^{47}$ and Mary

LetTer QuAdRAgesimo AnNo (1931) (Pius XI Depression-era encyclical expanding on the church's embrace of workers' rights to organize into unions, earn a living wage, and receive state assistance when necessary); Zachary A. Goldfarb and Michelle Boorstein, Pope Francis Denounces 'Trickle-Down' Economic Theories in Critique of Inequality, Wash. Post, (Nov. 26, 2013), http://www.washingtonpost.com/ business/economy/pope-francis-denounces-trickle-down-economic-theories-in-critiqueof-inequality/2013/11/26/e17ffe4e-56b6-11e3-8304-caf30787c0a9_story.html (Pope Francis, the former Jorge Bergoglio has labeled unfettered capitalism "a new tyranny," condemned the "idolatry of money," and denounced structural inequality that sentences so many millions of the world's citizens to abject poverty.).

42 Pope Benedict Xvi, Encyclical Letter Caritas Deus Caritas Est In VERITATE (2005).

${ }^{43}$ William Sloane Coffin, The Collected Sermons Of William Sloane Coffin: The Riverside Years, Volume 2 at 91 (2008).

${ }^{44}$ IMMANUEL KANT, LECTURES ON ETHICS 194 (Louis Infield trans., 1980). See also, Immanuel Kant, The Doctrine of Virtue in the Metaphysics of Morals 116 (M.J. Gregor trans., 1964) ("The ability to practice beneficence, which depends on property, follows largely from the injustice of government, which favours certain men and so introduces an inequality of wealth that makes others need help. This being the case, does the rich man's help to the needy, on which he so readily prides himself as something meritorious, really deserve to be called beneficence at all?”).

${ }^{45}$ Paolo Freire, Pedagogy of the Oppressed 28-29 (Myra B. Ramo trans., 1970).

47 Allen Buchanan, Justice and Charity, 97 Eтнісs 558, 558 (1987). See also RONALD DWORKIN, SOVEREIGN ViRTUE 266 (2002) ("We may try to live with only the resources we think we would have in a fair society, doing the best we can, with the surplus, to repair injustice through private charity. But since a just distribution [can only be established] through just institutions, we are unable to judge what share of our wealth is fair.”).

\footnotetext{
47 JaMes Boswell, Life OF JoHnson 217 (2004).
} 
Wollstonecraft ("It is justice, not charity, that is wanting in the world!”) ${ }^{48}$ bemoaned the elevation of charity over justice, as did Nelson Mandela ("And overcoming poverty is not a gesture of charity. It is an act of justice.”). ${ }^{49}$

Sociologist Janet Poppendieck gave the charity-justice conflict a book-length treatment in 1998's Sweet Charity?, her study of the U.S. system of food pantries and soup kitchens that sprung up as replacements for scaled-back anti-poverty entitlement programs. ${ }^{50}$ While praising the many dedicated providers she encountered in her research, Poppendieck concluded that society pays a substantial cost for their kindness. The most obvious cost is assessed at the point of contact, when recipients of charity often feel demeaned, even in settings where donors try to minimize the unavoidable hierarchy of benevolence. ${ }^{51}$ Catholic nun Sister Peggy Flanagan, a volunteer at a Salvation Army hot meal program, said, paraphrasing St. Vincent de Paul, "When you feed the poor, please ask for their forgiveness. You are giving them a bowl of soup, but they give up their dignity." ${ }^{2}$ As any mother forced to line up for help from the community food pantry can tell you, it truly is better to give than to receive.

Poppendieck identifies far broader damage flowing from the U.S. culture's preference for charity over rights. When a large majority of Americans report that they donate or volunteer for charity, it is not just a symptom of a society where the poor are forced to scramble for donated goods. It is a cause of that suffering as well. "The growth of kindness and the decline in justice are intimately interrelated,” Poppendieck writes. "This massive charitable endeavor serves to relieve pressure for more fundamental solutions." 53

Poppendieck extends the metaphor to argue that broad participation in — and awareness of — charitable efforts act as a "moral safety valve."54 Participating in a walk-a-thon for the homeless or donating a box of macaroni and cheese to the community food drive allows many Americans to avoid confronting the immorality of a society where great wealth ex-

${ }^{48}$ Mary Wollstonecraft, A Vindication of the Rights of Woman 40 (1792).

49 In Full: Mandela's Poverty Speech, BBC News (Feb. 3, 2005), http://news.bbc.co.uk/2/hi/uk_news/politics/4232603.stm.

50 Janet Poppendieck, SweEt Charity?: EMERgency FoOd AND THE END OF ENTITLEMENT (1998).

${ }^{51}$ Id. at 228-29, 232, 249. See also Reinhold Niebuhr, Moral MAN AND IMMORAL SOCIETY 127 (1932) ("[P]hilanthropy combines genuine pity with the display of power and that the latter element explains why the powerful are more inclined to be generous than to grant social justice.”).

52 Niagara Mothers' Union et AL., Working Together for Justice and Peace, CHARITY AND ADVOCACY: A GUIDE FOR DISCUSSION AND REFLECTION 4, http://voicesforchange.ca/uploaded/charity-to-justice-workshop-guide-2012.pdf.

${ }^{53}$ POPPENDIECK, supra note 51, at 5.

${ }^{54} I d$. 
ists alongside grinding poverty. ${ }^{55}$ Charity may not be very effective at alleviating long-term poverty, but it is quite good at alleviating American guilt about it.

Poppendieck characterizes most charitable efforts as unintentionally distracting rather than intentionally masking the problems of inequality. ${ }^{56}$ But other commentators point out that most comparatively wealthy charitable donors would not be displeased to know that donations from their excess help to perpetuate an unequal system that has richly rewarded them. ${ }^{57}$

There is also the undeniable reality that, for many concerned and compassionate Americans, it is simply preferable to be engaged in hands-on service as opposed to traveling the long, circuitous, and often frustrating path of activism for justice. As a physician who founded a Washington, D.C. community for homeless men with HIV/AIDS writes, "For most of us, the work of advocacy is less rewarding than day-today contact with needy people. It is less direct. As an advocate, I may never see significant change; I would rather immerse myself in direct service. And so the desperately needed work of advocacy is left undone."58

For heroes like these who devote their lives to charitable works, their exposure to unmet need deprives them of the luxury of avoidance. In her research, Poppendieck interviewed scores of operators and volunteers at emergency food programs, most of whom were quite aware of the limitations of the charity model in which they were immersed. ${ }^{59}$ Many antihunger leaders told Poppendieck that they feel trapped by the need to

${ }^{55}$ Id. at 198-99. See also C.S. LEWIS, YOURS, JACK: SPIRITUAL GUIDANCE FROM C.S. LEWIS 119 (2008) (Lewis is among those who have given voice to the notion that private charity can excuse a citizen from concerns over suffering they do not witness first-hand: "I think each village was meant to feel pity for its own sick and poor whom it can help and I doubt if it is the duty of any private person to fix his mind on ills which he cannot help. This may even become an escape from the works of charity we really can do to those we know.

${ }^{56}$ POPPENDIECK, supra note 51, at 301-02.

${ }^{57}$ Satyajit Das, Philanthropy Is Not Just Charity from the Rich: It's Self-Serving, Independent, (Dec. 16, 2014), http://www.independent.co.uk/ news/business/comment/philanthropy-is-not-just-charity-from-the-rich-its-selfserving-

9927181.html(“[Philanthropy by the wealthy] is an exercise in damage control against any backlash by the less well-off. Its perspectives are self-serving, promoting views beneficial to the business and financial interests of the wealthy. . . . The paradox of philanthropy is that enrichment by various [harmful] means paves the way for conspicuous generosity.”); David Hilfiker, Justice and the Limits of Charity, DavidHilfiker.com (Sept.-Oct., 2000), http://www.davidhilfiker.com/index.php?option=com_ content\&view=article\&id=13:limits-of-charity\&catid=8:justice-essays\&Itemid=17

("Charity does little to change the wider social and political systems that sustain injustice. In fact, most charities depend heavily on the very volunteers, individual donors, and institutions that have prospered under the current systems. And people who have done well in a system are usually not interested in changing it drastically-in fact, they may be diametrically opposed.”).

${ }^{58}$ Hilfiker, supra note 58.

${ }^{59}$ PoppendieCK, supra note 51, at 289. 
[Vol. 23:1

address the direct suffering caused by a shredded safety net, and to promote the value of their own programs to donors. ${ }^{60}$ One rabbi who helped found a New York City soup kitchen told Poppendieck that she discourages people who seek to follow her path, urging them instead to look for opportunities to be an advocate for systemic change. ${ }^{61}$ But those who, like the rabbi, tackle the significant challenge of direct charity work often do not have the time to serve as advocates for justice. Consumed with the task of pulling the babies out of the river, they have no spare energy for a venture upstream for advocacy. It is a dilemma Poppendieck cites as one of the opportunity costs of the U.S. charitable model. ${ }^{62}$

\section{ELIMINATE THE U.S. CHARITABLE TAX DEDUCTION}

\section{A. An Inequitable Reward for the Wealthy}

The United States' uniquely high level of reliance on a charitable response to poverty is not just an artifact of culture or history. It is an approach formally sanctioned by government policy expressed in its most tangible manifestation: the tax code. ${ }^{63}$ Since 1917, U.S. law has allowed individuals, corporations, and estates to deduct as much as half of their annual taxable income in an amount equal to charitable gifts made to qualified nonprofit organizations. ${ }^{64}$ The "501(c)(3)" organizations that are eligible to receive tax-deductible gifts include charitable, religious, educational, and sports groups, among others. ${ }^{65}$ This U.S. tax deduction provides the most generous incentive for charitable giving of any developed nation. ${ }^{66}$ As economist Joseph Schumpeter said over a half-century ago, "Nothing shows so clearly the character of a society and of a civilization as does the fiscal policy that its political sector adopts.”67

\footnotetext{
${ }^{60} \mathrm{Id}$.

${ }^{61} \mathrm{Id}$.

${ }^{62}$ Id. at 299-303.

${ }^{63}$ See, e.g., Susan Pace Hamill, An Evaluation of Federal Tax Policy Based on Ju-
} deo-Christian Ethics, 25 VA. TAX REV. 671, 752 (2006) (“Given that nearly eighty percent of Americans claim to adhere to Christianity or Judaism in some form, why is our tax policy at both the national and state levels continuing to move further away from reflecting genuine Judeo-Christian values?”).

${ }^{64}$ See 26 U.S.C. § 170(b)(1)(A). The deduction for charitable contributions has existed since 1917; see War Revenue Act of 1917, ch. 63, § 1201(2), 40 Stat. 330 (1917).

6526 U.S.C. § 170 (c).

${ }^{66}$ Rob Reich, A Failure of Philanthropy: American Charity Shortchanges the Poor, and Public Policy is Partly to Blame, Stan. Soc. Innovation Rev. (Winter, 2005), http://www.ssireview.org/articles/entry/a_failure_of_philanthropy.

${ }^{67}$ Joseph A. SCHUMPETER, History OF ECONOMIC ANALYSIS 769 (1954). See also Liam Murphy and Thomas Nagel, The Myth of Ownership: TaXes and Justice 188 (2002) ("Nothing could be more mundane than taxes, but they provide a perfect setting for constant moral argument and possible moral progress."). 
The most obvious effect of this policy is a loss of tax revenue. ${ }^{68}$ For a U.S. taxpayer at the highest marginal rate of 39.6\%, every dollar in charitable contributions reduces their tax obligation by nearly 40 cents. $^{69}$ The estimated annual cost of charitable tax deductions is $\$ 40$ billion in lost revenue, ${ }^{70}$ an amount more than three times the annual federal budget for the program Temporary Assistance to Needy Families ("TANF"). ${ }^{71}$ The deduction thus acts to transfer money-and poweraway from democratically elected government and hand them to individual donors.

The resulting nonprofit sector funded by these tax-deductible gifts has been called "the hidden welfare state."72 But it is the kind of welfare state that government-mistrusting Americans can live with, Yale law professor Stephen Carter has written. "The [charitable] deduction is democracy in action," Carter says. ${ }^{73}$

Except that it isn't. The nonprofit sector is radically elitist in that it places decision-making power firmly in the hands of our country's most wealthy residents. ${ }^{74}$ By definition, the rich possess the most disposable income and can afford to donate more than others of lesser means. ${ }^{75}$ That disproportionate control over the nonprofit sector, sometimes referred to as a "plutocratic bias," is further buttressed by two characteristics of the charitable tax deduction. ${ }^{76}$ First, the majority of lower and middle-income Americans file their taxes without itemizing their deduc-

68 JOINT COMMITTEE ON TAXATION, BACKGROUND INFORMATION ON TAX EXPENDITURE ANALYSIS AND HistORICAL SURVEY OF TAX EXPENDITURE Estimates, (2011),https://www.jct.gov/publications.html?func=startdown\&id=3740 (2010-2014 estimated revenue cost of charitable tax deduction is \$182.4 billion); REICH, supra note 67 (noting that the charitable contributions deduction is the fourth largest (out of 130) tax expenditure given to individuals, after deductions for mortgage interest, contributions to 401(k) plans, and state and local taxes).

69 See 26 U.S.C. § 1(a)-(d) (2014).

70 Congressional Budget Office, The Distribution of Major Tax ExPENDITURES IN THE INDIVIDUAL INCOME TAX $\quad$ System $17 \quad$ (2013), http://www.cbo.gov/sites/default/files/43768_DistributionTaxExpenditures.pdf.

${ }^{71}$ Department of Health AND Human SERVICES AdMinistration FOR ChILdREN AND Families, Temporary Assistance for NeEdy Families, FY 2012 Budget (2012), http://www.acf.hhs.gov/sites/default/files/olab/tanf.pdf.

72 See, e.g., Christopher HOWARD, THE HidDEN WElfare State: TAX Expenditures and SOCIAL POLICY IN THE United StATES (1999).

73 Carter, supra note 20.

74 See, e.g., Francie Ostrower, Why the Wealthy Give: The Culture of Elite PHILANTHROPY 29 (1995) ("Elite philanthropy involves far more than monetary contributions. . . . [G]iving does not occur in isolation, but is part of an overall involvement with nonprofit organizations.”); Opinion, Ray Madoff, A Better Way to Encourage Charity, N.Y. Times, October 5, 2014 (describing how many wealthy donors put their tax-exempt money into private foundations or donor-advised funds so they can maintain significant control even after they benefit from their deduction).

75 Some commentators say that donations by the wealthy are, at their core, selfserving. See Das, supra note 58.

${ }^{76}$ Rob Reich, Toward a Political Theory of Philanthropy, in Giving WeLl: ThE ETHICS OF Philanthropy 177, 184 (Patricia Illingworth et al. eds., 2011). 
tions. ${ }^{77}$ They get no tax benefit from their charity. Second, even the minority of modest-income donors who do claim charitable tax deductions benefit less from their gifts than do more wealthy donors since wealthy donors' tax rates are higher. ${ }^{78}$

The result is a skewed reward system. Three-quarters of the tax money saved via charitable deductions goes to donors with annual incomes over $\$ 500,000$, even though these people's donations total just a little more than half of all charitable gifts. ${ }^{79}$ U.S. taxpayers with incomes under $\$ 50,000$ gave $20 \%$ of all charitable donations, but benefitted from only $5 \%$ of the total deduction subsidy. ${ }^{80}$

The fundamentally inequitable nature of the charitable tax subsidy is illustrated by Charles Clotfelter, a Duke University economist who has written extensively on U.S. tax policy. Noting that Americans of more modest means tend to donate most to religious organizations, Clotfelter points to a hypothetical fundraising effort to put a new steeple on a Methodist church in Kansas. ${ }^{81}$ The $\$ 50,000$ raised for the steeple comes from smaller individual donations by parishioners who, like most Americans, do not itemize their tax deductions. ${ }^{82}$ No government revenue was lost by this effort. But the wealthiest Americans favor higher education with their gifts, and they are sure to itemize their deductions. ${ }^{83}$ So, Clotfelter notes, a comparable $\$ 50,000$ donation to the Stanford University athletics department by a high-income donor would have a very different effect. ${ }^{84}$ The gift would be de facto subsidized by other U.S. taxpayers in

${ }^{77}$ Andrew Lundeen \& Scott A. Hodge, Higher Income Taxpayers Are Most Likely to Claim Itemized Deductions, TAX Foundation (November 07, 2013), http://taxfoundation.org/blog/higher-income-taxpayers-are-most-likely-claim-itemizeddeductions.

${ }^{78}$ See Richard H. Thaler, It's Time to Rethink the Charity Deduction, N.Y. TIMES, Dec. 18, 2010 ("The government subsidizes charitable gifts from certain households .... To qualify, taxpayers must have a substantial home mortgage; the subsidy rate increases with taxable income. Low-income taxpayers receive no subsidy, but donations from qualified high-income taxpayers are subsidized by as much as 40 percent - or more.”) Thaler proposes changing the deduction to a tax credit, making the subsidy even for all donors, and allowing the tax credit only for donations over a minimum percentage of gross income.

${ }^{79}$ Congressional Budget Office, supra note 71, at 15.
80 Sweetened Charity, THE
ECONOMIST (June 9, 2012),

http://www.economist.com/node/21556570.

${ }^{81}$ Charles T. Clotfelter, Charitable Giving and Tax Policy in the U.S. 5-6, 10 (May 7, 2012) (unpublished manuscript) (on file with the Paris School of Economics), http://www.parisschoolofeconomics.eu/IMG/pdf/may2012-paris-clotfelter.pdf.

${ }^{82} \mathrm{Id}$. at 10.

${ }^{83}$ See, e.g., Donations to U.S. Colleges and Universities Increased 8.2 Percent In 2011, Nat'l. Ass'n C. \& U. Bus. Officers, (Feb. 16, 2012), http://www.nacubo.org/ Research/Research_News/Donations_to_US_Colleges_and_Universities_ Increased_82_in_2011.html.

${ }^{84}$ Clotfelter, supra note 82 , at $10-11$. 
the amount of $\$ 17,500$, the tax that a wealthy donor in the $35 \%$ bracket avoided paying by making the gift. ${ }^{85}$

The nonprofit sector is not just profoundly un-democratic, it also fails to produce anything resembling a "hidden welfare state" — at least a welfare state that would benefit those most in need. The legal parameters for organizations eligible for the 501(c)(3) designation are quite broad, meaning that tax-deductible gifts can go to support college football teams, opera companies, and rare bird sanctuaries just as easily as they can be directed toward domestic violence shelters. ${ }^{86}$ Historically, highincome donors have shown a preference for gifts to higher education, health, and the arts. ${ }^{87}$ The majority of donations given by Americans are to religious organizations, which direct only about $5 \%$ of those gifts to social services. $^{88}$

Despite the charitable tax deduction defenders' insistence that "the social good of the deduction far outweighs the money it costs," 89 it turns out that a quite limited amount of U.S. donations have the effect of transferring resources from rich Americans to poorer ones. ${ }^{90}$ Some tax-

\footnotetext{
${ }^{85} \mathrm{Id}$.

${ }^{86}$ See, e.g., Kent Faulk, Nick Saban Sold Home to Crimson Tide Foundation for \$3.1 Million in 2013, AOL News, (Oct. 26, 2014), http://www.al.com/news/birmingham/index.ssf/2014/10/crimson_tide_foundation_bough t.html (Alabama not-for-profit corporation directs funds to provide housing to the university's football coach, whose salary is estimated at $\$ 7$ million per year.).

${ }^{87}$ See Doug Donovan, Ben Gose \& Maria Di Mento, Gifts Surge From Rich U.S. Donors, CHron. OF PhIlANTHROPY., (Feb. 9, 2014), http://philanthropy.com/article/Gifts-Surge-From-Rich-U-S/144601/ (Colleges, foundations, and hospitals received the most gifts worth \$1-million or more in 2013, followed by medical research facilities, arts organizations, and human-service groups.); see also Kaitlin Mulhere, Deep-Pocket Donors, InsidE Higher ED, Jan. 28, 2015, https://www.insidehighered.com/news/2015/01/28/2014-record-year-higher-ed-donations (Charitable donations to colleges reached an all-time high of nearly $\$ 38$ billion in 2014, with 28.6 percent of the total given to fewer than 2 percent of the roughly 1,000 institutions that participated in the Council for Aid to Education's survey.).

${ }^{88}$ Robert Wuthnow, Saving America? Faith-Based Social Services and the Future Of CiviL Society 49 (2004). See also Joseph J. Cordes, Re-Thinking the Deduction for Charitable Contributions: Evaluating the Effects of Deficit-Reduction Proposals, 64 NAT'L TAX J. 1019, 1024 (2011) (Religious nonprofits claim the largest share of U.S. contributions, at $33.3 \%$ of the overall contributions.).

${ }^{89}$ Three-Fourths of Americans Favor Charitable Tax Deduction: Survey Indicates Any Changes to System Would Face Strong Opposition, Dunham \& Company, (Feb. 7, 2012), http://dunhamandcompany.com/2012/02/three-fourths-of-americans-favorcharitable-tax-deduction/.

${ }^{90}$ Indiana University Center on Philanthropy, Patterns of Household CHARITABLE GiVING BY INCOME GROUP, 2005 (2007), http://www.philanthropy.iupui.edu/files/research/giving_focused_on_meeting_needs_of_ the_poor_july_2007.pdf (less than one-third of the money individuals gave to nonprofits in 2005 was focused on the needs of the economically disadvantaged.). See also Reich, $A$ Failure of Philanthropy, supra note 67 ("[W]e should then stop kidding ourselves that charity and philanthropy do much to help the poor.”).
} 
deductible donations, such as those to foundations that support alreadywealthy school districts, actually act to increase inequality.

Most Americans do not know this. The charitable model is singularly well-marketed in the United States, as warm public service announcements and glossy annual reports trumpet how well nonprofits meet the community's needs. ${ }^{92}$ These efforts have succeeded, with a clear majority of Americans reporting a belief that nonprofits are better at promoting social welfare than government programs. ${ }^{93}$ And rising levels of economic segregation mean that non-poor Americans are rarely confronted by the realities of poverty. ${ }^{94}$ American Enterprise Institute president Arthur Brooks, writing earlier this year in the magazine Commentary, directly addressed conservative Americans in an effort to puncture any illusions of charity's impact. ${ }^{95}$ "It would be wonderful if America could solve all its problems of poverty and need through private charity," he wrote. "But even in this remarkably charitable country...private donations cannot guarantee anywhere near the level of assistance that vast majorities of Americans across the political spectrum believe is our moral duty." 96

The absence of a meaningful anti-poverty impact from donated dollars is particularly discouraging when compared to the opportunity lost due to tax revenue that could have been spent on proven government assistance programs like food stamps, unemployment compensation and housing assistance. ${ }^{97}$ Even in their underfunded condition here in the United States, such programs are more efficient than comparable charity efforts, and are credited with lifting more than 40 million people out of poverty each year. $^{98}$

${ }^{91}$ See Rob Reich, Opinion, Not Very Giving, N.Y. TimEs, (September 4, 2013), http://www.nytimes.com/2013/09/05/opinion/not-very-giving.html?_r=1\&.

${ }^{92}$ See Peter Panepento, How Much Should Nonprofit Groups Spend on Marketing?, CHRON. OF PHILANTHROPY (Nov. 18, 2009), http://philanthropy.com/blogs/giveandtake/how-much-should-nonprofit-groups-spendon-marketing/10370 (quoting nonprofit advisor suggestion that organizations spend 10$20 \%$ of their budget on marketing).

${ }^{93}$ DunHam \& Co., supra note 90.

${ }^{94}$ See Patrick Sharkey, Rich Neighborhood, Poor Neighborhood: How Segregation Threatens Social Mobility, BRookings (Dec. 5, 2013, 12:30 PM), http://www.brookings.edu/blogs/social-mobility-memos/posts/2013/12/04-howsegregation-threatens-mobility.

95 Arthur C. Brooks, 'Be Open-Handed Toward Your Brother', Commentary (Feb. 1, 2014), http://www.commentarymagazine.com/article/be-open-handed-toward-yourbrothers-1/.

${ }^{96} \mathrm{Id}$.

${ }^{97}$ See Konczal, supra note 30 ("Patchy and spotty as it is, today’s [U.S.] welfare state backstopped the economy during the Great Recession, and is still capable of providing broad security for the American people.”).

${ }^{98}$ See Robert Greenstein, Commentary: How Effective Is the Safety Net?, CTR. ON

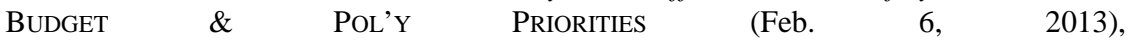
http://www.cbpp.org/cms/index.cfm?fa=view\&id=3898\#_ftn2 (finding that government 


\section{B. Exposing the Charity Illusion}

In support of a local effort to raise the minimum wage, I sometimes give talks to service organizations and community groups. ${ }^{99}$ As part of the presentation, I outline the daily challenges faced by the low-income workers we serve in our law school clinic. ${ }^{100}$ For example, I often talk about a local hotel housekeeper who gets down on her hands and knees each day to scrub other people's toilets, but cannot afford health insurance for herself. ${ }^{101}$ She earns so little that it can be a struggle to keep food on the family table. The hotel worker is perpetually on the verge of eviction and homelessness, and she has her already meager paycheck garnished to pay off healthcare and housing debts. ${ }^{102}$

After these talks, I can count on at least one person to approach me with a particular question. He sees no need to raise her wages. In fact, he is puzzled by the housekeeper's struggles. "Why," he asks, "can't she just go to a food pantry?” By this time, others have usually gathered around the questioner, and they nod their heads. They have been wondering the same thing.

This enduring American delusion owes its existence in part to the U.S. charitable tax deduction. The deduction is an elitist, ineffective policy creation that harms the poor and forces an inequitable burden on the middle class. Worse, the deduction lulls the nation into a false sense of complacency about our poverty crisis. ${ }^{103}$ It is time to eliminate it.

I am not the first to suggest this. In 2012 budget debates, when President Obama proposed a cap on charitable deductions, others took the

safety net programs lift one of every seven Americans out of poverty, an amount exceeding forty million people); Joanne W. Hsu, David A. Matsa \& Brian T. Melzer, Positive Externalities of Social Insurance: Unemployment Insurance and Consumer Credit 4 (Nat'l Bureau of Econ. Res., Working Paper No. 20353, 2014), http://www.nber.org/papers/w20353 (estimating that expansions of unemployment insurance from 2008 to 2012 prevented 1.4 million foreclosures); Diane Archer, Medicare is More Efficient Than Private Insurance, HeAlth AfF. Blog (Sept. 20, 2011), http://healthaffairs.org/blog/2011/09/20/medicare-is-more-efficient-than-private-

insurance/ (finding that administrative costs in Medicare are only about two percent of operating expenditures, compared to an estimated seventeen percent of revenue for private health insurance).

${ }^{99}$ My presentations are usually conducted on behalf of the organization Raise the Wage Indiana. See RAISE THE WAGE INDIANA, www.raisethewagein.org.

100 Clinical Courses, Ind. U. Robert H. McKinney SCH. OF L. (2015), http://mckinneylaw.iu.edu/courses/clinics.cfm.

${ }^{101}$ See Fran Quigley, If We Can Win Here: The New Front Lines of the Labor Movement 1-9 (2015) (describing narrative of the Indianapolis hotel housekeeper, Keisha Johnson).

${ }^{102} I d$.

${ }^{103}$ See, e.g., Poppendieck, supra note 51, at 5, 26-27; see also Warren Goldstein, William Sloane Coffin Jr.: A Holy Impatience 142 (2008) (quoting the question posed to Solon, the law-giver of Athens: "When will perfect justice come to Athens?" And the answer: "When those who are not the victims of injustice feel just as keenly as those who are.”). 
opportunity to push further. ${ }^{104}$ Citing the unequal benefits the deduction provides to wealthy donors, Cato Institute senior fellow Daniel Mitchell wrote a Wall Street Journal column arguing that high-income Americans can forego the deduction, especially since they already benefit from the premium symphony seats or named university buildings that reward their generosity. ${ }^{105}$ The Economist made a similar point in an article that quoted William Gladstone's 1863 speech to the House of Commons. ${ }^{106}$ The working class should not be subject to greater tax obligations to compensate for a wealthy citizen's charitable donation that already brought the donor "credit and notoriety," Gladstone argued. ${ }^{107}$

Eliminating the charitable tax deduction would lead to billions in increased tax revenue each year. ${ }^{108}$ For example, that revenue could be directed to pre-school education for poor children instead of a college stadium suite with a donor's name on a plaque over the door. ${ }^{109}$ Even more importantly, eliminating the charitable deduction would allow for a long overdue reckoning with our country's crisis of inequality. ${ }^{110}$ It would destroy the illusion that discretionary charity diverted from the excess accumulated by our nation's wealthy constitutes either an ethical or effective societal response to hunger, homelessness, and illness. The moral safety valve provided by tax-deductible charity should be shut off. $^{111}$

An illustration of the charity illusion was provided in the 2012 discussion of lowering the charitable tax deduction-it survived that year's budget debate intact-when a lobbyist for the nonprofit sector defended the deduction in a newspaper column. ${ }^{112}$ As an illustration of the deduc-

\footnotetext{
${ }^{104}$ See Jonathan Weisman, Democrats Like a Romney Idea on Income Tax, N.Y. Times (November 12, 2012), http://www.nytimes.com/2012/11/13/us/politics/ democrats-like-a-romney-idea-to-cap-tax-deductions.html?pagewanted=all.

${ }^{105}$ Daniel J. Mitchell, Should We End the Tax Deduction for Charitable Donations?

Yes: It Doesn't Increase Giving, WALL ST. J. (Dec. 16, 2012), http://www.wsj.com/articles/SB10001424127887324469304578143351470610998

${ }^{106}$ Sweetened Charity, supra note 81.

${ }^{107}$ Id.

${ }^{108}$ CONGressional Budget OfFICE, supra note 71, at 17.

${ }^{109}$ Compare Adrienne Lu, Head Start Hit With Worst Cuts in its History, USA TODAY (Aug. 20, 2013, 10:24 AM), http://www.usatoday.com/story/news/nation/ 2013/08/19/stateline-head-start/2671309/, with Phil Rishe, Thank You, Phil Knight: Oregon's New \$68 Million Recruiting Tool, Forbes (Aug. 3, 2013, 7:13 PM), http://www.forbes.com/sites/prishe/2013/08/03/thank-you-phil-knight-oregons-new-68million-recruiting-tool/ (Nike CEO Phil Knight and wife have donated over \$300 million to the University of Oregon and its athletic department over the past 20 years).

110 Drew DeSilver, U.S. Income Inequality, On Rise for Decades, is Now Highest Since 1928, Pew Res. Ctr. (Dec. 5, 2013), http://www.pewresearch.org/fact-tank/2013/12/05/u-s-income-inequality-on-rise-fordecades-is-now-highest-since-1928/.

${ }^{111}$ See generally POPPENDIECK, supra note 51 at 99.

${ }^{112}$ Diana Aviv, Should We End the Tax Deduction for Charitable Donations? No: Nonprofits Are in Dire Need of Funds, WALL ST. J. (Dec. 16, 2012, 4:08
} 
tion's utility, she cited the Congressional extension of allowable deductions for donations made in response to Haiti's devastating earthquake of January, 2010. ${ }^{113}$ Indeed, that U.S. tax law did achieve a narrow goal: nearly half of all U.S. households donated to Haitian relief efforts. ${ }^{114}$ But, as I, and others, have written elsewhere, those generously-funded Haitian relief and recovery efforts were disastrously implemented. ${ }^{115}$ The characteristic flaws of a charitable response to social crises-a lack of coordination among hundreds of isolated nonprofit efforts, the elevation of donor interests and non-profit visibility over the needs of those to be served-are on full, painful display in still-struggling Port-au-Prince today. ${ }^{116}$ Yet, it is likely that most 2010 U.S. donors to Haitian relief feel that, due in part to their generosity, Haitians' needs were effectively addressed. ${ }^{117}$ The poor continue to suffer; the donors have moved on. This is the inherent dynamic of the charitable model.

None of this is to say that the U.S. nonprofit sector does not have value. Acts of discretionary compassion can, and should supplement a broad system that guarantees each individual her right to the essentials of life. ${ }^{118}$ Small-scale charitable programs can provide valuable examples of innovation, developing methods that improve the comprehensive systems that address social needs. ${ }^{119}$ Similar benefits from private efforts can be found on an individual level. Volunteerism and donations can provide the first-hand exposure to inequality and suffering that moves a charity-focused individual to become an advocate for justice. Persons

PM),http://www.wsj.com/news/articles/SB1000142412788732446930457814335147061 0998

${ }^{113} \mathrm{Id}$.

${ }^{114}$ See Haiti Dominates Public's Consciousness: Nearly Half Have Donated or Plan to Give, PEW RES. CTR. (Jan. 20, 2010), http://www.peoplepress.org/2010/01/20/haiti-dominates-publics-consciousness/.

${ }^{115}$ See Mark Schuller, Killing With Kindness: Haiti, International Aid, And NGOs 5 (2012); Justin Elliott \& Laura Sullivan, How the Red Cross Raised Half-a-Billion Dollars for Haiti and Built Six Homes, Pro Publica (June 3, 2105), https://www.propublica.org/article/how-the-red-cross-raised-half-a-billion-dollars-forhaiti-and-built-6-homes; Fran Quigley, How Human Rights Can Build Haiti 84-110 (2014).

${ }^{116}$ See e.g., Fran Quigley, Things Are Difficult: A Post-Earthquake Disaster in Haiti, COMMON DREAMS (April 12, 2013), http://www.commondreams.org/ views/2013/04/12/things-are-difficult-post-earthquake-disaster-haiti.

${ }^{117}$ See Three-Fourths of Americans Favor Charitable Tax Deduction, supra note 89.

${ }^{118}$ See Burton A. Weisbrod, Toward a Theory of the Voluntary Non-Profit Sector in a Three-Sector Economy, in Altruism, Morality, And Economic Theory 171 (1975) (Not-for-profit sector complements private and government sectors by providing services when majoritarian government sector does not reflect wishes of minority of people).

119 See e.g., Nicholas D. Kristof \& Sheryl WuDunn, A Path Appears: Transforming Lives, Creating Opportunities 311 (2014) (making the case for private charity, but noting that large-scale improvements like a sanitation system or early childhood education program can only be accomplished by governments). 
stocking food pantry shelves join anti-hunger lobby groups. ${ }^{120}$ Bill Gates' experience making historically large charitable donations led him to embrace the role of champion for government-funded health programs and tax equity. ${ }^{121}$

So it is heartening to realize that eliminating the charitable tax deduction would not doom the U.S. nonprofit sector. Evidence over time shows that donations appear to be tied more to a rise in wealth rather than the tax treatment of gifts. ${ }^{122}$ The giving from modest-income donors who do not itemize currently ill be unaffected by eliminating the deduction they do not benefit from. ${ }^{123}$ As for the wealthy, there is a vigorous debate about the importance of the charitable deduction on decisions to donate. ${ }^{124}$ But the most persuasive evidence questions the importance of charitable tax deduction in spurring decisions to give. ${ }^{125}$ It

${ }^{120}$ See e.g., Latest Reflection from FUPC - Bread for the World Volunteer Libby McDermott, First United Presbyterian Church Of Cambridge, http://www.fupccambridge.org/news/201312/latest-reflection-fupc-bread-world-volunteer-libbymcdermott (Volunteer both at food pantries and for advocacy group Bread for World writes, "[I work with] direct food assistance programs (soup kitchens, food pantries, etc.) and [on] the political and social reality that makes these programs necessary. To end hunger we take care of our neighbors and make sure they have enough food on a daily basis, but we must also tackle the tough questions about why our neighbors are poor in the first place and do what we can to change a broken and unfair system.”).

${ }^{121}$ See Bill Gates, 2014 Gates Annual Letter: Three Myths That Block Progress For The Poor, Gates Foundation (2014), http://www.gatesfoundation.org/ Who-We-Are/Resources-and-Media/Annual-Letters-List/Annual-Letter-2014 ("It is ironic that the foundation has a reputation for a hard-nosed focus on results, and yet many people are cynical about the government aid programs we partner with.”); Tanya Somanader, Billionaire Bill Gates Calls For Increasing Taxes On The Rich: 'That's Just Justice', Think Progress, (Jan. 25, 2012), http://Thinkprogress.Org/Economy/2012/01/25/411283/Bill-Gates-Taxes-Justice/.

122 See U.S. Charitable Giving Estimated To Be \$307.65 Billion in 2008, FUNDRAISING SUCCESS (June 10, 2009), http://www.fundraisingsuccessmag.com/article/2008-us-charitable-giving-estimated30765-billion-408218/1 (2008 recession triggered only the second reduction in charitable giving in over a half-century, yet giving continued to reflect just over two percent of GDP); Joanne G. Carman \& Richard M. Clerkin, Snap Poll: Increases in Tax Rates Will Not Greatly Affect Charitable Giving, Philanthropy J. (Apr. 15, 2013), http://pj.news.chass.ncsu.edu/?p=32700 (poll results consistent with 100 years of charitable giving data showing that Americans give roughly two percent GDP annually regardless of increases or decreases in tax rates).

${ }^{123}$ Clotfelter, supra note 81.

${ }^{124}$ See, e.g., Gerald E. Auten et al., Taxes and Philanthropy Among the Wealthy, in Does Atlas Shrug? The Economic Consequences Of Taxing The Rich 392, 392 (Joel B. Slemrod ed., 2000); Patrick E. Tolan, Jr., Compromising the Safety Net: How Limiting Tax Deductions for High-Income Donors Could Undermine Charitable Organizations, 46 SuFFOLK U. L. REV. 329, 331-332 (2013) (predicting negative impact on contributions if deduction lowered or eliminated); Ray D. Madoff, What Leona Helmsley Can Teach Us About the Charitable Deduction, 85 CHI.-Kent L. Rev. 957, 964 (2010) (suggesting charitable giving amounts are resistant to influence of tax policy).

${ }^{125}$ See, Center On Philanthropy At Indiana University, The 2012 Bank Of America Study Of High Net Worth Philanthropy: Issues Driving Charitable Activities Among Wealthy Households 56, 71 (Nov. 
turns out that the same intrinsic rewards that motivate Americans to volunteer, such as the desire to give back to the community and to set an example for others, act to inspire donations as well. ${ }^{126}$ Along with more external benefits such as recognition in the community, these rewards have a far greater impact on giving than tax policies do. ${ }^{127}$ No less of a philanthropist than Warren Buffett says that tax implications are irrelevant to the charity decisions of the significantly wealthy. ${ }^{128}$

However, it would be naïve to pretend that eliminating the charitable tax deduction would have no negative impact on the U.S. nonprofit sector. ${ }^{129}$ On balance, though, that is not a bad thing. If the deduction goes away, it is likely there would be a downsizing of charitable institutions. Their hierarchical benefactor-recipient model would be less prevalent, as would their heavily marketed messages designed to convince potential donors that the needs of the poor are far better covered than they are in reality. ${ }^{130}$ Stripped of these illusions, compassionate Americans would join their counterparts in similar nations and support strengthening government-operated institutions that respect all humans as holders of enforceable rights, rather than holders of a beggar's cup. ${ }^{131}$ The vacuum created by the elimination of the charitable tax deduction should be filled by the ratification of the International Covenant on Economic, Social and Cultural Rights.

\section{U.S. RATIFICATION OF THE INTERNATIONAL COVENANT ON ECONOMIC, SOCIAL AND CULTURAL RIGHTS}

The second stage of the proposed remedy for the U.S. imbalance between justice and charity is the replacement of the charitable tax deduction with the long-delayed U.S. ratification of the International Covenant on Economic, Social and Cultural Rights. ${ }^{132}$ Ratification of the ICESCR would profoundly reshape the nation's approach to addressing the needs of all Americans.

2012),http://newsroom.bankofamerica.com/files/press_kit/additional/2012_BAC_Study_ of_High_Net_Worth_Philanthropy_0.pdf (49.9\% of high net worth households said their giving would be unaffected if the charitable deduction was eliminated, less than $10 \%$ said it would dramatically decrease. The highest proportion (74\%) of high net worth donors reported giving to charity because "they were moved at how their gift could make a difference.”).

${ }^{126}$ See id.; Dan Kadlec, Why Limiting the Charity Tax Deduction Won't Destroy Charities, TIME (Dec. 7, 2012), http://business.time.com/2012/12/07/why-limiting-the-charity-taxdeduction-wont-destroy-charities/ (reporting survey results where less than $13 \%$ of donors say they are motivated by tax deductions).

${ }^{127} \mathrm{Id}$.

${ }^{128}$ Sweetened Charity, supra note 80.

${ }^{129}$ See Auten et al., supra note 124; Toler, supra note 124.

${ }^{130}$ See Panepento, supra note 92.

${ }^{131}$ See OECD FACTBOOK 2014, supra note 4.

132 International Covenant on Economic, Social and Cultural Rights, supra note 7. 


\section{A. History of Economic and Social Rights}

The notion of individuals possessing certain economic and social rights existed long before there were international treaties and institutions designed to define and protect those rights. As noted above, all major religious traditions, and virtually all philosophical approaches, articulate a mandate to provide for the needs of the poor and sick, and most have done so using language that invokes justice and rights, not mere charity. ${ }^{133}$ Many individual governments have long embraced a responsibility to provide food and shelter for the indigent, as evidenced by provisions in the $18^{\text {th }}$ century Prussian General Code, the $19^{\text {th }}$ century Norwegian Constitution, multiple French constitutions, the social insurance programs of late $19^{\text {th }}$ century Germany, and U.S. poor relief systems from the same era. ${ }^{134}$ In the early $20^{\text {th }}$ century, the constitutions of Mexico, the Soviet Union, and the Weimar Republic all articulated a governmental obligation to address economic and social needs. ${ }^{135}$ On the multilateral level, the Treaty of Versailles in 1919 created the International Labour Organization ("ILO”), which eventually adopted standards regarding child labor, work hours, and insurance in the event of injury, illness, and old age. ${ }^{136}$

In the United States, state constitutions adopted in the $19^{\text {th }}$ and $20^{\text {th }}$ centuries often included rights to education, and some articulated rights to health and general welfare. ${ }^{137}$ Beginning in the $19^{\text {th }}$ century, states implemented poor relief programs. ${ }^{138}$ In the 1930 's, New Deal legislation created ambitious and successful federal social programs designed to counteract the effects of the Great Depression, including social security and unemployment insurance and multiple efforts that provided government-paid employment to supplement family incomes. ${ }^{139}$ These pro-

\footnotetext{
${ }^{133}$ See supra notes 30-43 and accompanying text.

${ }^{134}$ See A World MADE NEW, supra note 35, at 185-86.

${ }^{135}$ Id. See also David P. Currie, Positive and Negative Constitutional Rights, 53 U. CHI. L. ReV. 864, 868 (1986).

${ }^{136}$ See e.g., Convention Limiting the Hours of Work in Industrial Undertakings to Eight in the Day and Forty-Eight in the Week (adopted Nov. 28, 1919, entered into force June 13, 1921); Convention Concerning Minimum Standards of Social Security (adopted June 28, 1952, 210 U.N.T.S. 131, entered into force Apr. 27, 1955); Convention Concerning Minimum Age for Admission to Employment, (adopted June 26, 1973, 1015 U.N.T.S. 298. entered into force 19 Jun 1976).

${ }^{137}$ Cathy Albisa \& Jessica Schultz, The United States: A Ragged Patchwork, in SOCIAL RIgHTS JURISPRUDENCE: EMERgING TRENDS IN INTERNATIONAL AND Comparative LAW (Malcolm Langford, ed., 2008) at 240.

${ }^{138}$ See Philip Harvey, Joblessness and the Law Before the New Deal, 6 GEO. J. ON Poverty L. \& POL'Y 1, 11-41 (1999) (review of English and U.S. poor relief systems); Theda Skocpol, Protecting Soldiers and Mothers: The Political Origins of Social Policy In THE United STATEs (1992) (U.S. had social welfare programs for soldiers and their dependents and for mothers and dependent children in the late 19th and early 20th century).

${ }^{139}$ See Michael Hiltzik, The New Deal: A Modern History (2011).
} 
grams survived both significant political resistance and challenges to their constitutionality. ${ }^{1}$

President Franklin Roosevelt sought to build on the success of that legislation, and the impending end of World War II, in his 1944 State of the Union address, where he laid out an agenda he called a "second Bill of Rights”:

We have come to a clear realization of the fact that true individual freedom cannot exist without economic security and independence. "Necessitous men are not free men." People who are hungry and out of a job are the stuff of which dictatorships are made.

In our day these economic truths have become accepted as self-evident. We have accepted, so to speak, a second Bill of Rights under which a new basis of security and prosperity can be established for all regardless of station, race, or creed.

Among these are:

The right to a useful and remunerative job in the industries or shops or farms or mines of the Nation;

The right to earn enough to provide adequate food and clothing and recreation;

The right of every farmer to raise and sell his products at a return which will give him and his family a decent living;

The right of every businessman, large and small, to trade in an atmosphere of freedom from unfair competition and domination by monopolies at home or abroad;

The right of every family to a decent home;

The right to adequate medical care and the opportunity to achieve and enjoy good health;

The right to adequate protection from the economic fears of old age, sickness, accident, and unemployment;

The right to a good education.

${ }^{140}$ See Nat'l Labor Relations Bd. v. Jones \& Laughlin Steel Corp., 301 U.S. 1 (1937) (upholding the constitutionality of New Deal labor legislation on the basis that the affected practices impacted interstate commerce, thus allowing for federal intervention under Article I sec. 8 of the U.S. Constitution). A Commerce Clause rationale was later used by the Court to validate federal legislation on other human rights issues, including race discrimination. See, e.g., Atlanta Motel v. United States, 379 U.S. 241 (1964) (Title II of the Civil Rights Act of 1964 ruled a valid exercise of Congress' power under the Commerce Clause as applied to a place of public accommodation serving interstate travelers). 
All of these rights spell security. And after this war is won we must be prepared to move forward, in the implementation of these rights, to new goals of human happiness and well-being. ${ }^{141}$

Roosevelt's Second Bill of Rights followed his 1941 State of the Union address outlining the Four Freedoms: freedom of speech, freedom of worship, freedom from want, and freedom from fear. ${ }^{142}$ Both of these Roosevelt speeches' embrace of economic and social rights animated the deliberations of the new United Nations, as it considered the terms of the Universal Declaration of Human Rights ("UDHR"), which is demonstrated by a June 1947 U.S. draft of the Declaration that included significant support for economic and social rights. ${ }^{143}$ Roosevelt's widow, Eleanor Roosevelt, served as the first U.S. representative to the UN Human Rights Commission, and chaired the Commission and the committee that drafted the UDHR. ${ }^{144}$ She largely joined in the support for the Declaration's Articles 22 through 28, which include the rights to social security, unemployment protection, an adequate standard of living, and free primary education. ${ }^{145}$ On December 10, 1948, the UN General Assembly passed the Declaration without a dissenting vote. ${ }^{146}$ Together with its two implementing treaties, the International Covenant on Civil and Political Rights and the ICESCR, the three documents are considered to constitute the International Bill of Rights. ${ }^{147}$

\section{B. The International Covenant on Economic, Social and Cultural Rights}

The ICESCR articulates the right to social security; ${ }^{148}$ the right to free primary education; ${ }^{149}$ the right to work, including the right to remu-

${ }^{141}$ Franklin Delano Roosevelt, President, United States of America, Annual Message to Congress on the State of the Union (January 11, 1944), http://www.presidency.ucsb.edu/ws/index.php?pid=16518. At least one commentator says that Roosevelt's speech may be the greatest of the $20^{\text {th }}$ century. See Lincoln Caplan, The Legal Olympian: Cass Sunstein and the Modern Regulatory State, Harv. Mag., JanFeb. 2015, http://harvardmagazine.com/2015/01/the-legalolympian\#.VJSslGlbqR4.email.

${ }^{142}$ Franklin Delano Roosevelt, President, United States of America, Annual Message to Congress on the State of the Union (January 6, 1941), http://www.presidency.ucsb.edu/ws/index.php?pid=16092.

${ }^{143}$ Sally-Anne Way, The "Myth" and Mystery of US History on Economic, Social, and Cultural Rights: The 1947 "United States Suggestions for Articles to be Incorporated in an International Bill of Rights”, 36 HUM. RTS. Q. 868 (2014).

144 See GLENDON, supra note 35, at 33.

${ }^{145}$ Id. at $156-60$.

${ }^{147} 1948-1949$ U.N.Y.B., U.N. Sales No. 150.I.2.

${ }^{147}$ See generally Francesco Francioni, An International Bill of Rights: Why It Matters, How It Can Be Used, 32 Tex. InT'L L.J. 471 (1997).

${ }^{148}$ International Covenant on Economic, Social and Cultural Rights, supra note 7, at Art 9.

${ }^{149}$ Id. at Art. 13. 
neration that equates to fair wages and the provision of a decent living; ${ }^{150}$ the enjoyment of the highest attainable standard of physical and mental health; ${ }^{151}$ and the right to an adequate standard of living, defined as adequate food, clothing, and housing. ${ }^{152}$ The right to be free from hunger is identified in the text as "fundamental." 153 Despite its title, the Covenant does not explicitly place rights in categories of economic, social, and cultural, and such distinctions among the rights are generally ignored. ${ }^{154}$ The Covenant was adopted by the UN General Assembly in 1966. As of late 2014, 162 states are parties to the Covenant. ${ }^{155}$

The Covenant's Article 2 places qualifications on a state's immediate obligations, allowing it to "take steps . . . to the maximum of its available resources" to eventually "achieve progressively the full realization of the rights" in the Covenant. ${ }^{156}$ The inclusion of such broad rights under an abstract mandate like "progressive realization" led to the creation, in 1985, of the Committee on Economic, Social and Cultural Rights, known as the ESCR Committee. ${ }^{157}$ The Committee is made up of 18 independent expert members, hailing from different geographical regions and serving four-year terms. ${ }^{158}$ The Committee reviews reports that state parties to the Covenant are required to submit within two years of ratifying the Covenant, and every five years thereafter. ${ }^{159}$ The reports outline the states' compliance with the Covenant, including the steps taken toward the promised "full realization" of the enumerated economic and social rights. ${ }^{160}$ As is the case in other human rights treaty reporting processes, the ESCR Committee is often best informed by critiques of the party state's compliance submitted by non-governmental organizations (NGO’s) or other advocates. ${ }^{161}$ The Covenant's Optional Protocol

\footnotetext{
${ }^{150}$ Id. at Arts. 6-7.

${ }^{151}$ Id. at Art. 12.

${ }^{152}$ Id. at Art. 11.

${ }^{153}$ Id. at Art. 11, 92.

${ }^{154}$ Henry J. Steiner, Philip Alston \& Ryan Goodman, International Human Right in Context: Law, Politics, Morals 276 (2007).

${ }^{155}$ United Nations Treaty Collection, Status of International Covenant on Economic, Social and Cultural Right, https://treaties.un.org/ pages/viewdetails.aspx?chapter=4\&lang=en\&mtdsg_no=iv-3\&src=treaty.

${ }^{156}$ International Covenant on Economic, Social and Cultural Rights, supra note 7, at Art. 2.

${ }^{157}$ U.N. Econ. \& Soc. Council Res. 1985/17, Supp. No. 1, U.N. Doc. E/1985/85, at 15 (May 28, 1985).

${ }^{158}$ United Nations Office of the High Commissioner of Human Rights, Committee on Economic, Social and Cultural Rights, http://www.ohchr.org/EN/HRBodies/CESCR/Pages/CESCRIndex.aspx.

${ }^{159}$ Provisional Rules of Procedure Adopted by the Committee at its Third Session, Rule 58, E.S.C., E/C.12/1990/4/Rev.1 (1989).

${ }^{160} \mathrm{Id}$.

${ }^{161}$ See generally AMNESTY INT'L, Holding Government to Account: A Guide to Shadow Reporting on Economic Social and Cultural Rights (2014), http://www.flac.ie/download/pdf/cescr_guide_to_shadow_reporting_final_20052014.pdf;
} 
of 2008 creates a complaint procedure where individuals and organizations can access a quasi-judicial process that receives and reviews charges of party states' non-compliance. ${ }^{162}$ Under the Optional Protocol, state parties may also agree to allow the Committee to make more general inquiries and recommendations on "grave or systematic violations" of the Convention. ${ }^{163}$

The Committee also issues General Comments, which have proven to be instrumental in clarifying states' duties under the Covenant. ${ }^{164}$ In particular, the Committee addressed "The Nature of State Parties' Obligations" in General Comment 3 in 1990, articulating a "minimum core" that has given shape to the broad outlines of the economic and social obligations owed to individuals:

On the basis of the extensive experience gained by the Committee, as well as by the body that preceded it, over a period of more than a decade of examining States parties' reports the Committee is of the view that a minimum core obligation to ensure the satisfaction of, at the very least, minimum essential levels of each of the rights is incumbent upon every State party. Thus, for example, a State party in which any significant number of individuals is deprived of essential foodstuffs, of essential primary health care, of basic shelter and housing, or of the most basic forms of education is, prima facie, failing to discharge its obligations under the Covenant. If the Covenant were to be read in such a way as not to establish such a minimum core obligation, it would be largely deprived of its raison d'être. By the same token, it must be noted that any assessment as to whether a State has discharged its minimum core obligation must also take account of resource constraints applying within the country concerned. Article 2 (1) obligates each State party to take the necessary steps "to the maximum of its available resources." In order for a State party to be able to attribute its failure to meet at least its minimum core

see also, U.N. Office of the High Comm'r of Human Rights, CESCR-International Covenant on Economic, Social and Cultural Rights 53 Session (10 Nov. 2014 - 28 Nov. 2014),http://tbinternet.ohchr.org/_layouts/treatybodyexternal/SessionDetails1.aspx?Sessi onID=822\&Lang=en (showing, for example, that more than two dozen civil society organizations submitted reports to the Committee to consider as it reviewed Romania's ICESCR compliance during the Committee's $53^{\text {rd }}$ session).

${ }^{162}$ G.A. Res. 63/117, Optional Protocol to the International Covenant on Economic, Social and Cultural Rights art. 2, U.N. Doc. A/RES/63/117 (Dec. 10, 2008).

${ }^{163} I d$. at art. 11, para. 2.

${ }^{164}$ See generally Kerstin Mechlem, Treaty Bodies and the Interpretation of Human Rights, 42 VAND J. TRANSNAT'L L. 905, 926-31 (2009); Philip Alston, The General Comments of the UN Committee On Economic, Social and Cultural Rights, 104 AM. SOC'Y INT'L L. PROC. 4 (2010). 
obligations to a lack of available resources it must demonstrate that every effort has been made to use all resources that are at its disposition in an effort to satisfy, as a matter of priority, those minimum obligations. ${ }^{165}$

The Committee's General Comments have also provided specific guidelines for compliance with many of the Covenant's provisions, including education ("The nature of this [free primary education] requirement is unequivocal."-Comment 11, 1999 ${ }^{166}$ ) and housing ("the right to housing should not be interpreted in a narrow or restrictive sense . . . it should be seen as the right to somewhere live in security, peace, and dignity."Comment 4, $1991^{167}$ ). The Committee has also employed the Comments process to refute any perception that the Covenant requires a socialist system of government: "[The Covenant does not demand] any particular form of government or economic system being used as the vehicle for the steps in question, provided only that it is democratic and that all human rights are thereby respected ....,"168

The ICESCR is far from being the only international legal instrument recognizing economic and social rights. In the decades since the passage of the Universal Declaration of Human Rights, most countries that have written new constitutions have included the rights to social security, food, health care, and housing. ${ }^{169}$ The ILO Conventions, ${ }^{170}$ the Convention on the Rights of the Child, ${ }^{171}$ the Convention on the Elimination of All Forms of Racial Discrimination, ${ }^{172}$ and the Convention on the Elimination of All Forms of Discrimination Against Women ${ }^{173}$ all reference a range of economic and social rights. The same is true for regional human rights treaties, including the African Charter on Human

${ }^{165}$ Comm. on Economic, Social, and Cultural Rights, General Comment No. 3: The Nature of States Parties’ Obligations, ๆ10, U.N. Doc E/1991/23 (Dec. 14, 1990).

${ }^{166}$ Comm. on Economic, Social, and Cultural Rights, General Comment No. 11: Plans of Action for Primary Education, art. 14, U.N. Doc E/C.12/1999/4 (May 10, 1999).

${ }^{167}$ Comm. on Economic, Social, and Cultural Rights, General Comment No. 4: The Right to Adequate Housing, art. 11, U.N. Doc E/1992/23 (Dec. 13, 1991).

${ }^{168}$ Comm. on Economic, Social, and Cultural Rights, supra note 166.

${ }^{169}$ Mark Tushnet, WeaK Courts, Strong Rights: Judicial ReVIEW AND Social Welfare Rights In Comparative CONSTITUTIONAL LAW 220 (2008). See also CASS Sunstein, Designing Democracy: What Constitutions Do 222 (2001).

${ }^{170}$ See supra note 137.

${ }^{171}$ G.A. Res. 44/25, 44 U.N. GAOR, 44th Sess., Supp. No. 49, U.N. Doc. A/44/736 (1989) (including obligations to ensure the survival and development of the child, art. 6, special care for children with disabilities, art. 23, and the highest attainable standard of health, art. 24).

${ }^{172}$ G.A. Res. 2106 (XX), U.N. GAOR, 20th Sess., Supp. No. 14, art. 5, U.N. Doc. A/6014 (Dec. 21, 1965), 660 U.N.T.S. 195 (including obligations to respect without discrimination economic and social rights generally, and housing and health and workplace rights in particular, art. 5).

${ }^{173}$ G.A. Res. 34/180, U.N. GAOR, 34th Sess., Supp. No. 46, at 193, U.N.Doc. A/34/46 (1979) (including obligations to respect without discrimination economic and social rights generally, and health care and family benefits in particular, arts. 12 and 13). 
and People's Rights, ${ }^{174}$ the European Social Charter, ${ }^{175}$ and the Protocol of San Salvador to the American Convention on Human Rights. ${ }^{176}$

In fact, the global response to poverty, suffering, and inequality is increasingly framed in the language of human rights. ${ }^{177}$ Former UN High Commissioner for Human Rights Mary Robinson said, "I am often asked what is the most serious form of human rights violations in the world today, and my reply is consistent: extreme poverty." ${ }^{178}$ The Vienna Declaration of the 1993 World Conference on Human Rights stated, "[T] he existence of widespread extreme poverty inhibits the full and effective enjoyment of human rights.” ${ }^{179}$ Nelson Mandela said that "[M]assive poverty and obscene inequality are such terrible scourges of our times-times in which the world boasts breathtaking advances in science, technology, industry, and wealth accumulation-that they have to rank alongside slavery and apartheid as social evils." ${ }^{180}$ Seventy years after Franklin Roosevelt made the case that economic and social needs are in fact rights deserving of fulfillment, that recognition has become the global norm-with the notable exception of Roosevelt's own United States of America.

\section{The United States and Economic and Social Rights}

Unlike most national constitutions, and the vast majority of constitutions adopted after World War II, the U.S. Constitution contains no explicit guarantees of economic or social rights. As Judge Richard Posner has written, "The men who wrote the Bill of Rights were not concerned that the federal government might do too little for the people, but that it might do too much for them." 181 The rights protected under the U.S.

${ }^{174}$ Organization of African Unity, African Charter on Human and People's Rights, adopted June 27, 1981, 1520 U.N.T.S. 217 (including the rights to health, work, and education in arts. 15-17).

${ }^{175}$ Council of Europe, European Social Charter, opened for signature Oct. 18, 1961, 529 U.N.T.S. 89 (including rights to fair remuneration for work, art. 4, and social security, art. 12).

176 Organization of American States, Additional Protocol (of San Salvador) to the American Convention on Human Rights in the Area of Economic, Social and Cultural Rights of 14 November 1988, 28 I.L.M 161 (1989) (including rights to food, art. 12, and unionization, art. 8).

177 See Poverty and Human Rights, AMnESTY InTERnATIONAL, http://www.amnestyusa.org/our-work/issues/poverty-and-human-rights.

${ }^{178}$ UNDP, Poverty Reduction and Human Rights: A Practice Note, at iv (2003), http://www.undp.org/content/dam/aplaws/publication/en/publications/democraticgovernance/dg-publications-for-website/poverty-reduction-and-human-rights-practicenote/HRPN_\%28poverty\%29En.pdf.

${ }^{179}$ World Conference on Human Rights, Vienna Declaration and Programme of Action, $\uparrow 14$, U.N. Doc. A/CONF.157/23 (June 25, 1993).

${ }^{180}$ See In Full: Mandela's Poverty Speech, supra note 49.

${ }^{181}$ Jackson v. City of Joliet, 715 F.2d 1200, 1203 (7th Cir. 1983), cert. denied, 465 U.S. 1049 (1983). Unlike most other democratic constitutions, the U.S. document was written before the advent of the modern welfare state. See Mary Ann Glendon, Rights in Twentieth Century Constitutions, 59 U. CHI. L. REV. 519, 521 (1992). 
Constitution fall almost exclusively into the civil and political rights category, with even the Constitution's protections against governmentsanctioned discrimination given a more limited interpretation than international law generally calls for. ${ }^{182}$

For a time in the mid- $20^{\text {th }}$ century, it appeared that the U.S. Supreme Court may read into the Constitution implicit guarantees of economic and social rights. ${ }^{183}$ In 1954, a unanimous Court in Brown v. Board of Education cited education as a prerequisite to the meaningful exercise of all rights as a citizen. ${ }^{184}$ The Court later struck down new-resident waiting periods for welfare benefits ${ }^{185}$ and ruled that the Due Process Clauses' protection of property interests encompassed welfare payments. ${ }^{186}$ In the latter case, Goldberg v. Kelly, the Court even quoted the Constitution's preamble when delivering a constitutional affirmation of the value of justice over charity:

[W]elfare ... can help bring within the reach of the poor the same opportunities that are available to others to participate meaningfully in the life of the community. . . Public assistance, then, is not mere charity, but a means to "promote the general Welfare, and secure the Blessings of Liberty to ourselves and our Posterity."

But the Court would go no further down the path toward enforceable economic and social rights. In 1973, the Court in San Antonio Independent School District v. Rodriguez rejected the notion of a federal constitutional right to education, ${ }^{188}$ and on multiple other occasions reaffirmed that most social and economic legislative classifications are immune from constitutional challenges under the Equal Protection Clause. ${ }^{189}$ The Court aggressively rejected an argument of implicit economic and social constitutional rights in the case of Deshaney v. Winnebago County Dept. of Social Services, ruling that the "Due Process Clauses generally confer no affirmative right to governmental aid, even where such aid may be

\footnotetext{
${ }^{182}$ See Albisa and Schultz, supra note 137 at 235. (“[I]nternational norms prohibit discrimination where it has either a discriminatory purpose or effect, while U.S. jurisprudence requires both simultaneously.” (emphasis added) (citing the International Convention on the Elimination of All Forms of Racial Discrimination).

${ }^{183}$ See Cass Sunstein, Why Does the American Constitution Lack Social and Economic Guarantees?, 56 SYRACUSE L. REV. 1, 22 (2005) (speculating that "Social and economic rights, American style” could have been established by the Court if Hubert Humphrey had defeated Richard Nixon in the U.S. Presidential election of 1968, thus allowing Humphrey to make several appointments to the Supreme Court).

${ }^{184}$ Brown v. Bd. of Education, 347 U.S. 483, 493 (1954).

185 Shapiro v. Thompson, 394 U.S. 618 (1969).

${ }^{186}$ See Goldberg v. Kelly, 397 U.S. 254, 264 (1970).

${ }^{187}$ Id. at 265 (quoting U.S. CONST. pmbl.).

188 San Antonio Indep. Sch. Dist. v. Rodriguez, 411 U.S. 1, 35 (1973).

${ }^{189}$ See, e.g., Id. at 40; Lindsay v. Normet, 405 U.S. 56, 74 (1972); Dandridge v.
} Williams, 397 U.S. 471, 485 (1970). 
necessary to secure life." ${ }^{190}$ Ultimately, when the U.S. executive and legislative branches in the late $19^{\text {th }}$ century and early $20^{\text {th }}$ century tore holes in the safety net once provided by welfare and food programs, there was no constitutional barrier protecting the poor from these devastating decisions by the political branches of government. ${ }^{191}$

Nor were those legislative and executive actions barred by the International Covenant on Economic, Social and Cultural Rights, as the United States is the only western democracy to have failed to ratify the Covenant. ${ }^{192}$ In 1966, under President Lyndon Johnson's administration, the United States voted in the UN General Assembly to adopt the Covenant. ${ }^{193}$ In 1978, President Jimmy Carter signed the Covenant and submitted it to the U.S. Senate for its advice and consent pursuant to Article II, Section 2 of the U.S. Constitution. ${ }^{194}$ But, although the International Covenant on Civil and Political Rights achieved Senate approval and was ratified by the United States in 1992, the Senate has never taken up the ICESCR and no presidential administration since Carter's has asked the Senate to do so. ${ }^{195}$

The lack of a federal constitutional or treaty obligation to honor economic and social rights does not mean such rights are completely foreign to U.S. approaches to domestic or international policy. As noted above, many state constitutions articulate rights to education, and some include language outlining a state government commitment to general welfare and public health. ${ }^{196}$ Some state courts have seized on these provisions, and the federal constitution's reservation of power to the states through the Tenth Amendment, to find enforceable economic and social rights for

\footnotetext{
${ }^{190}$ Deshaney v. Winnebago Cty. Dept. of Soc. Servs. 489 U.S. 189, 196 (1989).

${ }^{191}$ See generally R. Kent WeAver, Ending Welfare as We KNow It (2000) (reviewing 1990s welfare reform legislation, including the Personal Responsibility and Work Opportunity Act and the elimination of the entitlement program Aid to Families with Dependent Children); Stacy Dean and Dottie Rosenbaum, CTR. ON Budget Policy AND PRIORITIES, Snap Benefits Will Be Cut for Nearly All Participants in November 2013 (2013), http://www.cbpp.org/cms/?fa=view\&id=3899.

192. See U.N. Office of the High Comm'r of Human Rights, supra note 12.

${ }^{193}$ See G.A. Res. 2200A, supra note 7.

194 Jimmy Carter, Human Rights Treaties Message to the Senate (Feb. 23, 1978), http://www.presidency.ucsb.edu/ws/?pid=30399.

${ }^{195}$ See Philip Alston, U.S. Ratification of the Covenant on Economic, Social and Cultural Rights: The Need for an Entirely New Strategy, 84 AM. J. OF INTL. LAW 365, 377 (1990). (Even the Carter administration did not provide full-throated advocacy of the ICESCR. The president's representatives downplayed the mandates of the Covenant as only "a declaration of aims" without any commitment to present implementation. In accordance with the highly controversial U.S. practice of agreeing to human rights treaties only after first affixing reservations, understandings, and declarations aimed at blunting the treaties' enforceability against the U.S., the Carter administration recommended the Senate ratify the ICESCR only after it included the following "understanding": "The United States understands paragraph (1) of Article 2 as establishing that the provisions of Articles 2 through 15 of this Covenant describe goals to be achieved progressively rather than through immediate implementation.” See Carter, id.

${ }^{196}$ See AlBISA \& SCHULTZ, supra note 137.
} 
residents of those individual states. ${ }^{197}$ The New Deal protections of labor rights, social security, and unemployment compensation have retained their foothold in the U.S. system for several generations, and the 1960's U.S. "War on Poverty" led to increased social programs. ${ }^{198}$ At the international level, the United States in 1989 signed the Vienna Declaration of the Conference on Security and Co-operation in Europe (also known as the Helsinki process), agreeing that "the promotion of economic, social, cultural rights . . . is of paramount importance for human dignity and for the attainment of the legitimate aspirations of every individual." 199 The United States was also one of the nations that affirmed the interdependence of all human rights at the 1993 World Conference on Human Rights in Vienna. ${ }^{200}$ The U.S. State Department's annual Country Reports on Human Rights Practices includes reviews of labor rights. $^{201}$

But efforts to cement economic and social rights into U.S. law via treaty ratification have been met with spirited resistance. Concerns have included the potential for loss of sovereignty to a global cooperative, encroachment on individual states' rights under the U.S. system of federalism, and the allegedly socialist nature of economic and social rights. ${ }^{202}$ Some U.S. opponents have labeled the ICESCR as the "Covenant on Uneconomic, Socialist, and Collective Rights." ${ }^{203}$ More broadly, anti-ESCR sentiment echoes resistance that has been expressed to U.S. ratification of any human rights treaty. In the 1950's, Senator John W. Bricker proposed a series of constitutional amendments that would have significantly limited the capacity of the United States to enter into bind-

197 See Martha Davis, The Spirit of Our Times: State Constitutions and International Human Rights Law, 30 N.Y.U. Rev. L. \& Soc. ChANGE 359, 360 (2006) (Arguing that state courts are fertile ground for future economic and social rights advocacy via litigation); Barbara Stark, Economic Rights in the United States and International Human Rights Law: Toward an Entirely New Strategy, 44 HASTINGS L.J. 79, 98 (1992).

198 See generally Council on Economic Advisers, THe WAR On POVERTy 50 YEARS LATER: A PROGRESS REPORT (2014), http://www.whitehouse.gov/sites/default/files/docs/50th_anniversary_cea_report_-

_final_post_embargo.pdf. But, as noted above, some of these economic and social programs have been cut in the 1990s and early 21st century, see supra note 192.

${ }^{199}$ Conference on Security and Co-operation in Europe, Concluding Document from the Vienna Meeting, American Society of International Law, 28 I.L.M. 527, 534, para. 14 (1989).

${ }^{200}$ U.N. World Conference on Human Rights, Vienna Declaration and Programme of Action, American Society of International Law, 32 I.L.M 1661, 1665, para. 5 (1993) (declaring that "All human rights are universal, indivisible and interdependent and interrelated.”).

${ }^{201}$ U.S. Dept. of State, Human Rights Reports, http://www.state.gov/j/drl/rls/hrrpt/.

202 See Duncan B. Hollis, Executive Federalism: Forging New Federalist Constraints on the Treaty Power, 79 S. CAL. L. REV. 1327, 1381 (2006).

${ }^{203}$ Alston, supra note 195, at 366. 
ing treaties. ${ }^{204}$ The Eisenhower Administration responded by pledging not to submit any human rights treaties for Senate consideration. ${ }^{205}$

Nearly four decades later, the Covenant on Civil and Political Rights finally earned Senate approval. ${ }^{206}$ The Reagan administration State Department issued a 1981 memorandum attempting to define economic and social rights out of existence altogether, insisting that human rights in U.S. foreign policy were to be construed as solely political rights and civil liberties. ${ }^{207}$ Assistant Secretary of State Elliott Abrams defended the policy in testimony to Congress the following year: "[T]he rights that no government can violate, [i.e. civil and political rights], should not be watered down to the status of rights that governments should do their best to secure, [i.e. economic, social and cultural rights]."208 A Deputy Assistant Secretary of State for Human Rights in the Reagan administration labeled economic and social rights as "myths."209 Subsequent presidential administrations did not display the same overt level of hostility to the concept of economic and social rights, but did oppose international references to the rights to food and housing, ${ }^{210}$ and AIDS treatment. ${ }^{211}$

\section{Arguments Against U.S. Ratification of the ICESCR}

The sharp-edged rhetoric in opposition to economic and social rights can create a temptation to dismiss the U.S. resistance as reactionary or even xenophobic. But, often, there are principled objections to U.S. ratification of the ICESCR. Before delivering the argument in favor of ratification, it is important to outline these objections.

1. Economic and social rights are contrary to the law and character of the U.S.

The Bricker Amendment in the 1950s and the Reagan administration efforts in the 1980s are extreme examples, but their opposition did re-

\footnotetext{
${ }^{204}$ See generally DuAne TANANBaum, THE Bricker AmEndment CONTROVERSY: A TEST OF EISENHOWER'S POLITICAL LEADERSHIP (1988).

205 JEREMY A. RABKin, LAW Without Nations?: Why CONSTITUTIONAL GOVERNMENT REQUIRES SOVEREIGN STATES 125-26 (2005).

206138 CONG. REC. 8068-71 (1992).

${ }^{207}$ Excerpts from State Department Memo on Human Rights, N.Y. Times (Nov. 5, 1981), http://www.nytimes.com/1981/11/05/world/excerpts-from-state-departmentmemo-on-human-rights.html.

${ }^{208}$ Review of State Department Country Reports on Human Rights Practices for 1981: Hearing Before the Subcomm. on Human Rights and International Organizations of the H. Comm. on Foreign Affairs, 97th Cong. (1982) (statement of Elliott Abrams, Assistant Secretary of State, Bureau of Human Rights and Humanitarian Affairs).

${ }^{209}$ Paula Dobriansky, Deputy Assistant Sec'y, Human Rights and Humanitarian Affairs, Address before the American Council of Young Political Leaders, Washington, D.C. (June 3, 1988), in Dep't of State, Bureau of Public Affairs, Current Pol’y No. 1091, at 2).

${ }^{210}$ Stein et al, supra note 154, at 281.

${ }^{211}$ Albisa \& Schultz, supra note 137, at 230.
} 
flect a broader U.S. discomfort with economic and social rights. ${ }^{212}$ One argument against ratifying the ICESCR in the United States is that the treaty's obligations placed on the national government would contradict the U.S. legacy under the Tenth Amendment of granting to individual states the power to devise and implement economic and social programming. ${ }^{213}$ This federalism objection had an undeniably racist tint in the Bricker Amendment era-southern states did not want antidiscrimination treaty provisions to interfere with their Jim Crow practices. ${ }^{214}$ The extent of states' current autonomy in the economic and social arena eighty years after the New Deal is certainly debatable. ${ }^{215}$ But the federalism legacy in the United States retains a strong presence in public dialogue, especially when coupled with state constitutional provisions for economic and social rights. ${ }^{216}$

An even more deep-seated source of U.S. resistance to the ICESCR is its association with the collectivist philosophies of communism and socialism. ${ }^{217}$ Although the Cold War between capitalist and communist states is long concluded, the United States continues to define itself internally, and internationally, as an individualistic culture. ${ }^{218}$ In a country where "Don't Tread on Me" flags and bumper stickers are still quite prevalent, ${ }^{219}$ and a Tea Party anti-government movement has had significant political impact in the $21^{\text {st }}$ century, ${ }^{220}$ the limited-government character

${ }^{212}$ The U.S. has been slow to embrace even civil and political rights, as evidenced by its delayed ratification of the ICCPR and its history of attaching reservations, understandings, and declarations to the treaties it does ratify. See Harold Koh, The Future of Lou Henkin's Human Rights Movement, 38 Colum. HuM. RTS. L. REv. 487, 490 (2007). ("In the cathedral of human rights, the United States is more like a flying buttress than a pillar--choosing to stand outside the international structure supporting the international human rights system, but without being willing to subject its own conduct to the scrutiny of that system.”).

${ }^{213}$ Hollis, supra note 202.

${ }^{214}$ See e.g., Fuji v. State, 217 P.2d 481 (Cal. App. 1950), aff'd. on other grounds, 38 Cal. 2d 718, 242 P.2d 617 (1952) (demonstrating that The Bricker Amendment movement was spurred in part by decisions like the California Court of Appeals ruling in Fuji that the U.N. Charter equated to a binding treaty obligation that under the Supremacy Clause of the U.S. Constitution superseded inconsistent state legislation-in this case, restricting alien land ownership).

${ }^{215}$ See Cass R. Sunstein, Constitutionalism After the New Deal, 101 HARV. L. REv. 421, 425 (1987).

${ }^{216}$ See Stark \& Davis, supra note 197.

${ }^{217}$ See, e.g., Robert W. LeE, The United Nations Conspiracy 108 (1981); Alston, supra note 195, at 366.

${ }^{218}$ See, e.g., Sharon Jayson, What's On Americans' Minds? Increasingly, 'Me', USA Today, (Jul. 10, 2012, 6:29 PM), http://usatoday30.usatoday.com/ news/health/story/2012-07-10/individualist-language-in-books/56134152/1.

${ }^{219}$ See Tom Scocca, What is the Tea Party Waving, Exactly?, Boston Globe (June 13, 2010), http://www.boston.com/bostonglobe/ideas/articles/ 2010/06/13/flag_daze/.

${ }^{220}$ See William Galston, The Tea Party and the GOP Crackup, Wall St. J. (October 15, 2013, 6:52 $\quad$ PM), $\quad$ http://www.wsj.com/articles/ SB10001424052702303376904579135231053555194; Tami Luhby, Romney-Ryan 
of civil and political rights offers a more comfortable fit than the expansive government role anticipated by the ICESCR. ${ }^{221}$ One U.S. commentator's comparison of the different challenges for implementing civil and political rights versus economic and social rights contrasts the activist role for government in the economic and social arena with the limited "night watchman" role in protecting against violations of civil and political rights - and finds the night watchman role to be more appropriate. ${ }^{222}$ Some critics have derisively labeled the ICESCR as the "holidays with pay treaty.",223 A Cold War-era writer said, "[t]he Covenant is a socialist blueprint that encourages open-ended government meddling of the sort on which dictators thrive.”224 This concern dates back before the Covenant. American Bar Association president Frank Holman in 1948 labeled the Universal Declaration of Human Rights as "a proposal for worldwide socialism to be imposed in the U.S. and on every other member nation."225

2. Economic and social rights are inferior to civil and political rights

The United States' ratification of the International Covenant on Civil and Political Rights, which largely tracks the guarantees in the U.S. Constitution, is instructive. Even some staunch human rights advocates explicitly or implicitly elevate civil and political rights over economic and social rights. Aryeh Neier, a leading U.S. human rights activist who has directed Human Rights Watch and the American Civil Liberties Union, and served as president of the Open Society Institute, argues that a more just distribution of the world's resources cannot come from assertion of human rights. ${ }^{226}$ In fact, Neier and others believe that the necessarily uncertain markers gauging progressive realization of economic and social rights could lead to a watering down of civil and political rights:

With social and economic rights ... it is inevitable that they are going to be applied differently in different plac-

Would Overhaul Medicaid, Cnn Money (Aug. 13, 2012, 12:13 PM), http://money.cnn.com/2012/08/13/news/economy/ryan-medicaid/ (Rep. Paul Ryan, the Republican candidate for Vice President in 2012, saying the social welfare safety net is at risk of becoming "a hammock that lulls able-bodied people into lives of dependency and complacency, that drains them of their will and their incentive to make the most of their lives.").

${ }^{221}$ See Neier, supra note 9, at 31 (arguing that economic rights do not have their roots in "Natural Law" as civil and political rights do). But see note 192 supra (demonstrating that the ICESCR has been ratified by most capitalistic democracies, including all of the U.S.' closest economic allies in western Europe.).

${ }^{222}$ David Kelley, A Life of One's Own: Individual Rights and the Welfare STATE 26 (1998).

${ }^{223}$ Alston, supra note 195, at 368.

${ }^{224}$ Lee, supra note 217.

${ }^{225}$ Albisa \& Schultz, supra note 137, at 233.

${ }^{226}$ Aryeh Neier, Social and Economic Rights: A Critique, 13 Hum. RTs. BRIEF 1 (2006); see also Neier, supra note 9, at 68. 
es. That is, if you are talking about one country with extensive resources and one that is very poor, there is not going to be the same right to shelter or to health care... . But suppose that one takes that same idea - that different stages of development mean different things for each country - and applies it to the concept of civil and political rights. Suppose China or Zimbabwe says it is not a developed country and therefore cannot provide the same civil and political rights as a developed country ... Therefore, I think it is dangerous to allow this idea of social and economic rights to flourish ... ${ }^{227}$

Human Rights Watch is now openly advocating for economic and social rights, ${ }^{228}$ and Amnesty International also argues for economic and social rights as well as civil and political rights. ${ }^{229}$ But their advocacy in the economic and social rights arena is comparatively less robust, and $\mathrm{Hu}-$ man Rights Watch executive director Kenneth Roth has confessed to "a sense of futility” among traditional civil and political rights advocates making their way in the promotion of economic and social rights. ${ }^{230}$

Economic and social rights" "little brother" status to civil and political rights is an observable phenomenon even in states that have ratified the ICESCR, as the ESCR Committee noted with dismay in its statement to the Vienna World Conference in 1993:

"[S]tates and the international community as a whole continue to tolerate all too often breaches of economic, social, and cultural rights which, if they occurred in relation to civil and political rights, would provoke expres-

\footnotetext{
${ }^{227}$ Neier, supra note 226, at 2-3; see also Cass Sunstein, Against Positive Rights, 2 EAst Eur. CONST’L. REv. 35, 36 (1993) (“[T]here is a big difference between what a decent society and what a constitution should guarantee . . . If the Constitution tries to specify everything to which a decent society commits itself, it threatens to become a mere piece of paper, worth nothing in the real world . . . If the right to the highest possible level of physical health is not subject to judicial enforcement, perhaps the same will become true of the right to free speech and to due process of law.”). But, by 2001, Sunstein appeared to be more amenable to economic and social rights in constitutions. See Sunstein, supra note 170, at 223 ("If minimal socio-economic rights will be protected democratically, why involve the Constitution? The best answer is to doubt the assumption and to insist that such rights are indeed at systemic risk in political life, especially because those who would benefit from them lack political power. It is not clear if that is true in every nation. But it is certainly true in many places.”).

${ }^{228}$ See e.g., Human Rights WATCH, Human Rights Watch Submission to the United Nations Committee on Economic, Social and Cultural Rights in Advance of its Review on Greece August 2015, (August 25, 2015), https://www.hrw.org/news/2015/08/25/humanrights-watch-submission-united-nations-committee-economic-social-and-cultural.

229 See Economic, Social and Cultural Rights, AMNESTY INTERNATIONAL, http://www.amnesty.org/en/economic-social-and-cultural-rights.

${ }^{230}$ Kenneth Roth, Defending Economic, Social and Cultural Rights: Practical Issues Faced by an International Human Rights Organization, 26 HuM. RTs. Q. 63, 72 (2004).
} 
sions of horror and outrage ... In effect, despite the rhetoric, violations of civil and political rights continue to be treated as though they were far more serious, and more patently intolerable, than massive and direct denials of economic, social and cultural rights ... 231

In its struggle to enforce economic and social rights as vigorously as civil and political rights, the United States is clearly not alone.

3. Economic and social rights are not justiciable

As the statements of Neier and other advocates suggest, one source of their preference for civil and political rights is that those rights are seen to be justiciable in a way economic and social rights are not. As Neier has stated,

The concern that I have with economic and social rights is when there are broad assertions of the sort that appear in the Universal Declaration of Human Rights or that appear in the South African Constitution, which speak broadly of a right to shelter or housing, a right to education, a right to social security, a right to a job, and a right to health care. There, I think, we get into territory that is unmanageable through the judicial process and that intrudes fundamentally into an area where the democratic process ought to prevail. ${ }^{232}$

The argument that economic and social rights are "unmanageable through the judicial process," and thus not justiciable, can be reduced to two points: courts do not possess the legitimacy or the competency to adjudicate economic and social rights.

The legitimacy argument asserts, as Neier's statement suggests, that the judiciary is not the correct branch of government to be making decisions involving economic and social rights. ${ }^{233}$ A democratically-elected legislature and executive, with more transparent deliberative processes and direct accountability to the electorate are the proper bodies to be reaching decisions on economic and social matters. ${ }^{234}$ A judge-issued ruling on an alleged economic and social rights violation risks the possibility of "queue jumping," since the issue is presented to the court with-

${ }^{231}$ Comm. on Economic, Social, Cultural Rights on Eighteenth and Nineteenth Sessions, U.N. Doc E/1993/22, Ann. III, at 83 (1999).

${ }^{232}$ Neier, supra note 226.

${ }^{233}$ See Neier, supra note 9, at 83 ("Alexander Hamilton, writing in the Federalist Papers famously called the judiciary the 'least dangerous' branch of government because it has 'neither the power of the purse nor the power of the sword.'”).

${ }^{234}$ See Michael J. Dennis \& David P. Stewart, Justiciability of Economic, Social and Cultural Rights: Should There Be an International Complaint Mechanism to Adjudicate the Rights to Food, Water, Housing, and Health? 98 AM. J. InT’L. L. 462, 467 (2004). 
out the context of competing needs. ${ }^{235}$ If the courts do consider the broader economic and social landscape, the argument goes, there would be virtually no limit to their jurisdiction. As one scholar has written about adjudication of economic and social rights, "In the end, we would have the courts running everything - raising taxes and deciding how the money should be spent." 236

Concerns are also lodged about courts overstepping not just their political legitimacy, but also exceeding the boundaries of their competency. ${ }^{237}$ The worry is that economic and social rights are too complex, costly, and vague for judges to appropriately enforce. ${ }^{238}$ Courts lack taxing authority, along with the depth of knowledge and breadth of available interventions that are available to a bureaucracy. ${ }^{239}$ Confronted by these challenges, scholars have predicted, courts will limit themselves to a position of deference to the political branches. ${ }^{240}$ There are certainly examples of just that sort of judicial deference, including English Court of Appeals and South African Constitutional Court decisions that allowed the political branches to determine the scope of the right to health care. $^{241}$ In the case of $R v$. Cambridge Health Authority, ex parte B, involving a request to mandate the state-run health services to provide cancer treatment to a girl despite its low probability of success, the court wrote, "Difficult and agonizing judgments have to be made as to how a limited budget is best allocated to the maximum advantage of the maximum number of patients. That is not a judgment the court can make ...." ${ }^{242}$

${ }^{235}$ See James L. Cavallaro \& Emily J. Schaffer, Less as More: Rethinking Supranational Litigation of Economic and Social Rights in the Americas, 56 HASTINGS L.J. 217, 236-38 (2004).

${ }^{236}$ Mark Tushnet, Taking the Constitution Away from the Courts (1999) (Tushnet is among several scholars who have argued that courts' role in enforcing economic and social rights should be limited to citing economic and social rights violations but leaving the remedy to the political branches of government.); see also David Landau, The Reality of Social Rights Enforcement, 53 HARV. INT’L. L.J. 189, 192 (2012).

${ }^{237}$ See, e.g., Robert H. Bork, The Impossibility of Finding Welfare Rights in the Constitution, 1979 WASH. U. L.Q. 695, 700 (1979) (“Courts simply are not equipped, much less authorized, to make such decisions.”); Frank B. Cross, The Error of Positive Rights, 48 UCLA L. REV. 857, 924 (2001) ("The case [for economic and social rights] erroneously presumes that the courts can discern the policy best suited to achieving the desired consequential ends, when in fact the legislature is better suited for this goal.”).

${ }^{238}$ Alana Klein, Judging as Nudging: New Governance Approaches for the Enforcement of Constitutional Social and Economic Rights, 39 Colum. HuM. RTs. L. Rev. 351, 353-54 (2008).

${ }^{239}$ Sunstein, supra note 228.

${ }^{240}$ Frank I. Michelman, The Constitution, Social Rights, and Liberal Political Justification, 1 INT'L. J. ConsT. L. 13, 29 (2003).

${ }^{241}$ R v. Cambridge Health Auth., ex parte B (1995) 1 W.L.R. 898; see also Soobramoney v. Minister of Health, Kwazulu-Natal 1998 (1) SA 765 (CC) at 776 (S. Afr.).

${ }^{242}$ R v. Cambridge Health Auth., 1 W.L.R. at 906 (1995). 


\section{E. Arguments for U.S. Ratification of the International Covenant on Economic, Social and Cultural Rights}

1. Ratification of the ICESCR would lead to improved economic and social conditions for the U.S. poor

While it is beyond the scope of this article to lay out a strategy to push the United States toward ratification of the ICESCR, ${ }^{243}$ there is no question that ratification of the Covenant would be a transformative event in the evolution of the political and moral character of the United States. ${ }^{244}$ Human rights instruments are normative, meaning they create a set of expectations designed to spur governmental and societal behavior. ${ }^{245}$ The process of public discussions, official deliberations and eventual ratification of human rights treaties is sometimes compared to a cascade that eventually leads to better conditions for affected persons. ${ }^{246}$ Recent empirical research has confirmed widespread achievement of the normative goals of human rights treaties: improvements in the respect for, and protection of, human rights in countries that ratify the instruments. ${ }^{247}$ While full compliance with the ICESCR among its current

${ }^{243}$ Although there is a clear need for a modern and considered articulation of that strategy, blueprints for ratification efforts have been offered by scholars. See Alston, supra note 196; Robert Traer, U.S. Ratification of the ICESCR?, http://religionhumanrights.com/Law/ICESCR/usrat.icescr.htm; Barbara Stark, At Last? Ratification of the Economic Covenant as a Congressional-Executive Agreement, 20 Transnat'L L. \& ConTEMP. Probs. 107, 109 (2011) (“The Covenant faces difficult, but not insurmountable, obstacles. Ratification is no more improbable than the election of a black president.”).

${ }^{244}$ See, Megan McLemore, Dispatches: One More Healthcare Challenge for the U.S., HuMAN RightS WATCH, (June 29, 2015), https://www.hrw.org/news/2015/06/29/dispatches-one-more-healthcare-challengeus\#st_refDomain=\&st_refQuery (senior researcher at Human Rights Watch arguing that "human right to health" rhetoric by President Barack Obama and tangible gains achieved by the U.S. Affordable Care Act should be formalized by U.S. ratification of the ICESCR).

${ }^{245}$ Frank I. Michelman, Socioeconomic Rights in Constitutional Law: Explaining America Away, 6 InT’L. J. Const. L. 663, 667 (2008).

${ }^{246}$ Eibe Reidel, The Human Right to Water and General Comment No. 15 of the CESCR, in The Human Right to Water 19, 35 (E. Reidel \& P. Rothen, eds., 2006). See also Glendon, supra note 36, at 218 (discussing how the Universal Declaration of Human Rights helped spur the creation of global human rights advocacy organizations and how the 1975 Helsinki Accords helped spur freedom movements in the Soviet Union, Poland, Czechoslovakia and Hungary, despite the fact that neither document's human rights terms were binding).

${ }^{247}$ Christopher J. Farris, Respect for Human Rights has Improved Over Time: Modeling the Changing Standard of Accountability in Human Rights Documents, 108 AM. POL. SCI. REV. 297 (2014); Christopher J. Farris, The Changing Standard of Accountability and the Positive Relationship between Human Rights Treaty Ratification and Compliance, SOCIAL SCIENCE RESEARCH NETWORK (Nov. 16, 2014) http://ssrn.com/abstract=2517457 (arguing that changing standards of human rights accountability explain the opposite conclusions of Eric Neumayer, Do International $\mathrm{Hu}$ man Rights Treaties Improve Respect for Human Rights?, 49 J.OF CONFLICT RESOL. 925, 
parties is far from a reality, certain of its rights-including the right to primary school education and some food, housing, and labor rights-are widely respected. $^{248}$

The efficacy of human rights treaty instruments is derived not just from the language of rights but from the forums provided for asserting those rights and registering complaints when they have not been respected. ${ }^{249}$ The ESCR Committee has stated that a forum and access to remedies for rights violations are necessary for compliance with the Covenant. ${ }^{250}$ As Nolan, et al. have written, the process of formal "witness" has a special power to push the needle toward a greater respect for human rights: "Most people who have participated in human rights hearings at the domestic or regional level will have experienced a kind of pivotal moment in the adjudication of a human rights claim when, through the 'voice' of the rights claimant, the subjective struggle for dignity and security breaks through the legal argument to bring home the real issues of human dignity that are at stake in a claim.” 251

The United States' lack of a strong history of respecting economic and social rights provides a strong rationale for-not against - the adoption of the ICESCR, especially when viewed in the context of an unsatisfactory status quo: enduring and widespread U.S. poverty. ${ }^{252}$ U.S. exceptionalism in the economic and social rights arena is evidenced by the text of the U.S. constitution, the narrow judicial interpretation of that constitution in the context of economic and social rights, and the refusal to

944-49 (December 2005); Oona A. Hathaway, Do Human Rights Treaties Make a Difference? 111 YALE L.J. 1935, 1976-2000 (2002).). See, also, Michael O’Flaherty, Human Rights Law Makes a Difference, OpenGlobalRights, (Dec. 12, 2014) https://www.opendemocracy.net/openglobalrights/michael-o\%E2\%80\%99flaherty/ human-rights-law-makes-difference (eight-year member of UN Human Rights Committee, the treaty body that monitors implementation of the International Covenant on Civil and Political Rights, providing anecdotal evidence of rights strengthening related to treaty compliance).

${ }^{248}$ STEINER ET AL., supra note 155, at 282.

249 See Eva Brems \& Laurens Lavrysen, Procedural Justice in Human Rights Adjudication: The European Court of Human Rights, 35 HuM. RTS. Q. 176, 177-85 (Feb. 2013).

${ }^{250}$ See Comm. on Economic, Social, and Cultural Rights, supra note 165.

251 Aoife Nolan et al., The Justiciability of Social and Economic Rights: An Updated Appraisal, Center for Human Rights and the Global Justice Working Paper No. 15, 4 (2007).

${ }^{252}$ See Stark, supra note 243, at 113 ("[t] $]$ he norms of the Covenant are, in fact, norms that are widely accepted in the United States. Most Americans do not want mentally ill people to sleep on the street or children to go hungry"). Stark's assertion gains some support from popular rhetoric from some U.S. leaders, including Franklin Roosevelt's Four Freedoms, supra note 143; Dr. Martin Luther King's statement, "What good is it to have the right to sit at a lunch counter if you can't afford a hamburger," Peter Dreier, Martin Luther King Was a Radical, Not a Saint, Huff. Post, Jan. 20, 2013; and President Barack Obama's statement, "[I]t matters little if you have the right to sit at the front of the bus if you can't afford the bus fare." Senator Barack Obama, Remarks of Senator Barack Obama at the 99th Annual Convention of the NAACP (July 14, 2008), http://www.presidency.ucsb.edu/ws/index.php?pid=77650. 
[Vol. 23:1

ratify economic and social rights instruments. ${ }^{253}$ This gap in legal rights has contributed to the vacuum of economic and social justice, as well as the absence of effective state intervention on behalf of the poor and the sick of a comparatively wealthy country. ${ }^{254}$ Certainly, ratification of the ICESCR in the United States will necessitate overcoming the entrenched domestic political opposition to economic and social rights. But that challenge presents a blessing in disguise, as the thorough debate will ensure that eventual ratification will not create a dead letter, but will instead reflect a genuine, well-considered commitment by the American people to the principles of the Covenant. ${ }^{255}$

The U.S. popular affection for civil and political rights provides additional opportunities for argument in support of ICESCR ratification. Despite the separation of the International Covenant on Civil and Political Rights from the ICESCR, and rhetoric that has attempted to consign the two forms of rights to distant islands, the dichotomy is a false one. The interdependence and indivisibility of civil and political rights and economic and social rights was a defining feature of the Universal Declaration of Human Rights, ${ }^{256}$ and is a well-settled tenet of international law. ${ }^{257}$ The connection is also inescapably logical: starving children, mothers who do not survive childbirth due to lack of healthcare, and the desperately homeless cannot meaningfully exercise their rights to vote and free assembly. Amartya Sen's well-known assertion that a famine is unlikely to occur in a representative democracy with a free press is his illustration of the value of civil and political rights to economic and social well-being. ${ }^{258}$ But Sen and others have also cautioned that the exis-

${ }^{253}$ See supra notes 212-225; see also Lindsay v. Normet, 405 U.S. 56, 74 (1972) ("We do not denigrate the importance of decent, safe, and sanitary housing. But the Constitution does not provide judicial remedies for every social and economic ill."). But see LaWrence Sager, Justice in Plainclothes: A Theory of American Constitutional PRACTICE 84-102 (2004) (arguing that there exist “judicially underenforced” economic and social norms in U.S. constitutional law).

${ }^{254}$ See Michelman, supra note 245, at 673 ("Of course, it is true that each person, acting alone or in voluntary collaboration with others, can try in good faith to define and fulfill his or her individual, equitable obligation to aid the needy, regardless of what others in a position to help may or may not do. But frustration surely awaits whoever makes the attempt, and the argument seems very strong that our efforts along those lines are most effectively and satisfyingly directed toward inducing the state to tax us and others in order to pay for activities along the lines envisioned by FDR.”).

255 Alston, supra note 195, at 392-93 makes a similar argument.

${ }^{256}$ See Indivisibility and Interdependence of Economic, Social, Cultural, Civil, and Political Rights, G.A. Res. 44/130, U.N. GAOR, 44th Sess., Supp. No. 49, U.N. Doc. A/Res/44/130, at 209 (Dec. 15, 1989).

${ }^{257}$ See Vienna Declaration, supra note 200, § 5, at 5; International Conference on Human Rights, Proclamation of Tehran, \13, U.N. Doc. A/CONF.32/41 (Apr. 22-May 13, 1968); See also Craig Scott, Interdependence and Permeability of Human Rights Norms: Towards a Partial Fusion of the International Covenants on Human Rights, 27 Osgooode HaLl L.J. 769, 779-90 (1989).

${ }^{258}$ Amartya Sen, Freedoms and Needs, 210 NEw REPUBLIC 31, 33-34 (1994). 
tence of democracy is no guarantee of full economic and social rights. ${ }^{259}$ As professor Frances Stewart has said, "Capitalist democratic states put the emphasis on the private sector, which does not always deliver on social goods. The free press is good on major disasters like classic famines, but it tolerates chronic hunger as much as anyone else." ${ }^{260}$ Stated in a more positive way, democracy and economic and social rights are interdependent. ${ }^{261}$ Recognizing this interdependency, western democracies other than the United States embrace economic and social rights alongside similar civil and political rights commitments in their constitutions, their court decisions, and in their ratification of both the ICESCR and ICCPR. ${ }^{262}$ It is no coincidence that, compared to the United States, these same nations devote a greater percentage of their gross domestic product to meeting social needs, have lower poverty rates, and endure less inequality. ${ }^{263}$

\section{Economic and Social Rights are Justiciable in the United States}

In terms of justiciability, the two forms of rights also resist neat division. The standard Isaiah Berlin characterization of civil and political rights as negative rights and economic and social rights as positive rights has some broad validity, ${ }^{264}$ but it is inaccurate to say that the state does not incur substantial obligations in the protection of civil and political rights. A partial list of the substantial governmental undertakings to protect civil and political rights in the United States and elsewhere would include criminal courts, civil courts, jails and prisons, police officer hiring and training, government systems for recording and protecting private property, and extensive election apparatus. ${ }^{265}$ Although it has been

${ }^{259}$ See generally id.; World Conference on Human Rights, Statement to the World Conference on Human Rights on Behalf of the Committee on Economic, Social and Cultural Rights, ๆ 3, U.N. Doc. E/C.12/1992/2 (December 7, 1992) (“[T]here is, however, no basis whatsoever to assume that the realization of economic, social and cultural rights will necessarily accompany, or result from, the realization of civil and political rights.”).

${ }^{260}$ Michael Massing, Does Democracy Avert Famine?, N.Y. TimEs (Mar. 1, 2003), http://www.nytimes.com/2003/03/01/arts/does-democracy-avert-famine.html.

${ }^{261}$ Karl Klare, Critical Perspectives on Social and Economic Rights, Democracy, and Separation of Powers, in SOCIAL AND ECONOMIC Rights IN THEORY AND PRACTICE: CRITICAL Inquiries 1, 4 (Helena Alviar García et al. eds., 2015) (“[D]emocracy and SER [social and economic rights] are mutually constitutive - social and economic rights that are in some sense constitutionally binding are of the essence of democracy.") (emphasis omitted). See also Deval Desai, "Courting" Legitimacy: Democratic Agency and the Justiciability of Economic and Social Rights, 4 InTERDISC. J. HuM. RTS. L. 29, 42,46 (2010) (widespread absence of economic and social well-being among the polity undercuts the democratic legitimacy of the state).

${ }^{262}$ Alston, supra note 195, at 375-76. See also Glendon, supra note 181, at 519.

263 See Organization for Economic Co-Operation and Development, supra note 4, at 65, 67, 217; Gould \& Wething, supra note 24, at 2-6; Denk et al., supra note 24, at 13.

${ }^{264}$ See Berlin, supra note 8, at 121-22.

265 See Henry Shue, Basic Rights: Subsistence, Affluence, and U.S. Foreign POLICY 37-38 (1996). 
argued that economic and social rights are too complex for courts to rule on, adjudication of civil and political rights is often not a straightforward task either. ${ }^{266}$ Assessing the competing interests involved in a prisoner's claim to being subject to cruel and unusual punishment or a student's complaint of due process violations in public school expulsion, for example, are daunting for any court. ${ }^{267}$

Yet these U.S. judges muddle through civil and political rights cases like these, and find a way to provide remedies when appropriate and to defer to the other branches of government when that discretion is called for. ${ }^{268}$ They can do the same for economic and social rights. Despite arguments to the contrary, courts in the United States possess both the legitimacy and the competency to enforce the requirements of the ICESCR.

The opportunity to be heard and receive a ruling is at the core of rights enforcement, and the judicial branch of government is procedurally best suited for that role. ${ }^{269}$ Courts are often the most appropriate substantive fit as well. Arguments that courts lack legitimacy to adjudicate economic and social rights claims do not square with the U.S. courts' proud tradition as the branch of government that is most protective of the rights of individuals who are not members of majority ethnic, religious, or economic groups. ${ }^{270}$ If majoritarian decision-making is properly restrained by courts in the event of racial discrimination ${ }^{271}$ or persecution of minority religious groups, ${ }^{272}$ shouldn't courts also be entrusted to defend the rights of the minority who are politically marginalized due to hunger, homelessness, and lack of health care? ${ }^{273}$

${ }^{266}$ See Bork, supra note 237, at 700; Cross, supra note 237, at 900-24.

267 See, e.g., Holly Boyer, Home Sweet Hell: An Analysis of the Eighth Amendment's 'Cruel And Unusual Punishment' Clause as Applied to Supermax Prisons, 32 Sw. U. L. REV. 317, 332-33 (2003); Donald H. Stone \& Linda S. Stone, Dangerous \& Disruptive or Simply Cutting Class; When Should Schools Kick Kids to the Curb?: An Empirical Study of School Suspension and Due Process Rights, 13 J.L. \& FAM. STUD. 1, 2-7 (2011).

${ }^{268}$ Klare, supra note 261, at 19 (Courts determining when and whether to overrule legislative and executive decisions is not a new phenomenon: "The adoption of binding SER [social and economic rights] complicates but does not create the occasion or need for balancing exercises. That happened ages ago when reviewing courts first held that legislative action intruded impermissibly on fundamental rights.”).

${ }^{269}$ See Comm. on Economic, Social and Cultural Rights, supra note 166, § 5.

${ }^{270}$ See Chambers v. Florida, 309 U.S. 227, 241 (1940) (courts are "havens of refuge for those who might otherwise suffer because they are helpless, weak, outnumbered, or because they are nonconforming victims of prejudice and public excitement”). But see Barry Friedman, The Will of the PeOple: How Public Opinion has Influenced the Supreme Court And SHAPEd the MEAning of the Constitution (2009) (arguing that the U.S. Supreme Court's countermajoritarian reputation is not fully deserved).

${ }^{271}$ See, e.g., Brown v. Bd. of Educ., 347 U.S. 483 (1954).

272 See, e.g., Church of the Lukumi Babalu Aye v. Hialeah, 508 U.S. 520 (1993).

273 See Frank Michelman, Welfare Rights in a Constitutional Democracy, 1979 WASH. U. L. Q. 659, 678 (1979) (“To be hungry, afflicted, ill-educated, enervated, and demoralized by one's material circumstances of life is not only to be personally disadvantaged in competitive politics, but also, quite possibly, to be identified as a member of a group - call it 'the poor' - that has both some characteristic political aims and values 
It is possible that the political branches of the U.S. government will reliably protect economic and social rights post-ratification of the ICESCR, especially with the intervention of civil society pushing for such protections. ${ }^{274}$ But the influence of campaign contributions and lobbying by wealthy individual and corporate supporters, ${ }^{275}$ along with non-representative legislative apportionment due to electoral district gerrymandering, ${ }^{276}$ calls into question the political branches' reliability in protecting economic and social rights. Deval Desai argues that the judiciary has a role to play in the interpretation and enforcement of economic and social rights when the other branches of government are not truly representative of the polity due to the limited agency of those living in grinding poverty. ${ }^{277}$ Devai focuses his analysis on developing countries, but notes that the need for judicial oversight of economic and social rights in the United States is suggested by the sheer percentage of the population living below the poverty line and without essentials such as healthcare. ${ }^{278}$

Similarly, arguments that courts lack competency to adjudicate economic and social rights do not account for the adversarial legal process' ability to produce robust fact-finding and generate creative and effective remedies. ${ }^{279}$ In the judicial setting, expert witnesses, documentary evidence, amicus curiae (friend of the court) and third-party interveners, along with courts' capacity to appoint special masters and other expert adjudicators, all supplement the testimony of the directly-affected individuals and the arguments of counsel challenging every factual and legal

and some vulnerability to having its natural force of numbers systematically subordinated in the processes of political influence and majoritarian coalition-building.”).

${ }^{274}$ See, e.g., Social Movements and Grassroots Groups, INT’L NETWORK FOR ECON., Soc. \& CULtURAL Rights, http://www.escr-net.org/node/365085 (last visited Sept 18, 2015) (ESCR advocacy group mobilizing civil society to push for realization of ESCR rights); Neier, supra note 9, at 7 (Neier argues that the driving force behind decades of human rights protection has been nongovernmental advocacy organizations).

275 See Lynda W. Powell, The Influence of Campaign Contributions in State Legislatures (2012); John Craig \& David Madland, How Campaign Contributions and Lobbying Can Lead to Inefficient Economic Policy, Ctr. for Am. Progress 3 (May 2, 2014), https://www.americanprogress.org/issues/economy/report/ 2014/05/02/88917/.

${ }^{276}$ See Sam Wang, The Great Gerrymander of 2012, N.Y. Times (Feb. 2, 2013), http://www.nytimes.com/2013/02/03/opinion/sunday/the-great-gerrymander-of-

2012.html?pagewanted=all ("Democrats received 1.4 million more votes for the House of Representatives in 2012, yet Republicans won control of the House by a 234 to 201 margin.”).

${ }^{277}$ Desai, supra note 261, at 29-30.

${ }^{278}$ Id. at 47.

${ }^{279}$ For example, economic rights disputes are adjudicated in a judicial-style process in multilateral trade agreements, including General Agreement on Tariffs and Trade (GATT), North American Free Trade Agreement (NAFTA) and World Trade Organization (WTO). See Patricia Isela Hansen, Judicialization and Globalization in The North American Free Trade Agreement, 38 TEX. InT'L L.J. 489, 489-92 (2003). 
contention. ${ }^{280}$ As a result, advocates litigating economic and social rights find that judicial review brings out information and analysis that were not present in the political branch process. ${ }^{281}$

Any complaint that economic and social rights in the United States are vague compared to civil and political rights would be remedied by judicial interpretation of the Covenant on challenges brought by individuals and civil society, just as decades of case law has given shape to the abstract notions of privacy rights, due process, and other constitutional liberty considerations. ${ }^{282}$ Indeed, studies have shown that courts reviewing economic and social rights in other jurisdictions effectively balanced factors like resource limitations, popular demand, and infrastructure concerns. $^{283}$

As that track record suggests, the question of courts' competency to adjudicate economic and social rights is no longer a timely one. The matter is now well-settled, with courts and commissions reviewing claims and issuing orders regarding the right to clean water in Argentina, ${ }^{284}$ the right to food and housing in Nigeria, ${ }^{285}$ the right to child care and employment in Finland, ${ }^{286}$ the right to education for learningdisabled students in Canada, ${ }^{287}$ the right to housing for internally displaced persons in Colombia, ${ }^{288}$ the rights to subsistence grants for the

${ }^{280}$ See, e.g., Monroe H. Freedman, Our Constitutionalized Adversary System, 1 CHAP. L. REV..57 (1998) ("[T] he adversary system represents far more than a simple model for resolving disputes. Rather, it consists of a core of basic rights that recognize and protect the dignity of the individual in a free society.”).

${ }^{281}$ Nolan et al., supra note 250 , at 14.

${ }^{282}$ See, e.g., Akhil Reed Amar, The Bills of Rights: Creation and Reconstruction (2000) (The notion of the Bill of Rights protecting individual rights, much less the minority from the majority, did not take root until 19th-century post-Civil War reconstruction and the adoption of the 14th Amendment); Peter Irons, The Courage of Their Convictions (1990) (accounts of sixteen different individuals who asserted their rights in cases that made constitutional law).

${ }^{283}$ Varun Gauri \& Daniel M. Brinks, Introduction: The Elements of Legalization and the Triangular Shape of Social and Economic Rights, in COURTING SOCIAL JUSTICE: Judicial ENFORCEMENT OF SOCIAL AND ECONOMIC RIGHTS IN THE DEVELOPING WORLD 1, 5 (VARUN GAURI \& DANIEL M. BRINKS eds., 2008).

284 CApel.Civ., Neugen, sala II, 19/5/1997, Expte.311-CA-1997, “Menores Comunidad Paynemil s/acción de amparo”(Arg), www.escr-net.prg/docs/i/405963.

${ }^{285}$ SERAC and CESR v. Nigeria African Commission on Human Rights, [2002], Case No. 155/96, Decision made at 30th Ordinary Session, Banjul, The Gambia, from 13th to 27th October 2001. Summary available at http://www.escr-net.org/docs/i/404115.

${ }^{286}$ KKO 1997: 141 (Employment Act Case) Yearbook of the Supreme Court 1997 No. 141(Supreme Court of Finland), Case No. S 98/225 (Child-Care Services Case) Helsinki Court of Appeals 28 October 199; For English summaries of these and a wide range of other ESR cases, see CENTER ON HOUSING Rights AND EVICTIONS, LEADING CASES ON ECONOMIC, SOCIAL AND CUltural Rights: Summaries 44-45 (2009), http://www.cohre.org/sites/default/files/leading_esc_rights_cases_24_april_2009.pdf.

${ }^{287}$ Moore v. British Columbia, [2012] S.C.R. 61 (Can.).

${ }^{288}$ Corte Constitutional [C.C.] [Constitutional Court], enero 22, 2004, Sentencia T025/2004 (Colom.), www.brookings.edu/ /media/Research/Files/ Papers/2009/11/judicial\%20protection\%20arango/Annexes.PDF. 
unemployed in Germany, ${ }^{289}$ to name just a few of dozens of examples. $^{290}$ Professor Lucy Williams conducted an analysis of thirty two economic and social rights decisions from eight national jurisdictions and found the courts sometimes aggressively ordering the provision of social goods and "[m]uch less preoccupied with [separation of powers] concerns than academics and traditional jurists in the older constitutional democracies may imagine.”291 Any notion that economic and social rights are a mere paper tiger were put to rest long ago, as evidenced in particular by sweeping decisions by courts in India and South Africa.

In the case of People's Union for Civil Liberties v. Union of India, the Supreme Court of India was presented with claims based on the Indian government retaining a food surplus even as its citizens were suffering from a severe famine. ${ }^{292}$ Citing Article 21 of the Constitution of India, which protects every citizen's right to live with human dignity, the Court ordered the government to carry out food and employment programs, including school meals and provision of grain at reduced prices to impoverished families. ${ }^{293}$ Implementation of the orders, which involved millions of tons of grain and the expenditure of billions of rupees, was overseen by court-appointed commissioners. ${ }^{294}$ The court's ruling and implementation is considered to have saved thousands of lives. ${ }^{295}$ As one commentator observed about the Indian case and a Colombian Constitutional Court's orders for health care and housing for displaced persons, "In both cases, the court took on massive issues that the political branches had basically ignored and constructed public policy from the ground up."296

The South African Constitutional Court has generated a body of law on economic and social rights that illustrates both the rights' justiciability and the Court's exercise of restraint by leaving some decisions to the political branches of government. The Court's most celebrated decision, Minister of Health v. Treatment Action Campaign, relied on the right to healthcare services articulated in the South African Constitution to compel the government to provide the anti-retroviral medicine nevirapine to

\footnotetext{
${ }^{289}$ Hartz IV, BVerfGE 1BvL 10/10, 9.2.2010, Absatz-Nr. (1-220) (Ger.).

${ }^{290}$ Among the volumes that include summaries of court decisions involving economic and social rights are INTERNATIONAL COMMISSION OF JURISTS, COURT AND THE Legal EnForcement of ECONOMic, SOCIAL AND Cultural Rights (2008); Gauri \& Brinks, supra note 283; Albisa \& Schultz, supra note 138; CENTER ON Housing Rights AND EVICTIONS , supra note 286.

${ }^{291}$ Lucy A. Williams, Resource Questions in Social and Economic Rights Enforcement, in Social and Economic Rights in Theory AND Practice 60 (Helena Garcia et al., 2014).

${ }^{292}$ Writ Petition (Civil) No. 196 of 2001 (May 2, 2003) (interim order) (India), https://www.escr-net.org/docs/i/401033.

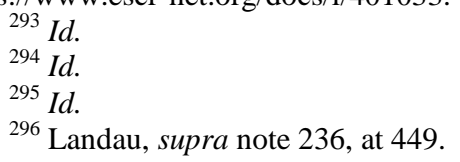


[Vol. 23:1

HIV-positive mothers and their babies at childbirth. ${ }^{297}$ A 2003 decision about housing rights in South Africa v. Grootboom favorably cited the housing rights in South Africa's constitution and the ICESCR. ${ }^{298}$ But the Grootboom decision was less prescriptive than the Treatment Action Center order, allowing the government significant leeway in implementing a plan to respect housing rights and declining to order specific relief for the plaintiff. ${ }^{299}$ In the Court's 1998 decision in Soobramoney v. Minister of Health, the Court refused to order the government to provide renal dialysis that was essential to the plaintiff's survival, citing the state's constitutional obligation to take only the actions that are possible

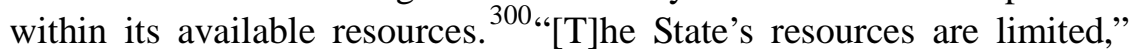
the Court wrote. "[T]here are also those who need access to housing, food and water, employment opportunities, and social security.” ${ }^{301}$ Ironically, despite the high-profile nature of the South African Constitutional Court's economic and social rights jurisprudence, and the fears of some commentators that courts will overreach in deciding cases involving economic and social rights, the Court has been criticized for not being proactive enough in making those rights meaningful for the country's poor. $^{302}$

Even in the absence of specific economic and social rights in its federal constitution, U.S. courts are no stranger to these types of cases. Structural injunction remedies like those issued in the People's Union for Civil Liberties and Treatment Action Center cases, and the civil society pressure that created and sustained the litigation, have their analogs in U.S. court decisions addressing challenges to prison conditions, ${ }^{303}$ public school financing, ${ }^{304}$ access to shelter for homeless persons, ${ }^{305}$ and housing discrimination. ${ }^{306}$ Just like People's Union for Civil Liberties

${ }^{297}$ Minister of Health v. Treatment Action Campaign (TAC) 2002 (5) SA 721 (CC) (S. Afr.).

${ }^{298}$ Government of the Republic of South Africa and Others v. Grootboom and Others 2001(1) SA 46 (CC) (S. Afr.).

${ }^{299}$ Id.

${ }^{300}$ Soobramoney v. Minister of Health (Kwazulu-Natal) 1997 (12) BCLR 1696 (CC) (S. Afr.).

${ }^{301} I d$. at para. 31.

${ }^{302}$ See, e.g., Landau supra note 236, at 197-98; David Bilchitz, Giving SocioEconomic Rights Teeth: The Minimum Core and its Importance, 119 S. AFR. L. J. 484, 491 (2002); Sandra Liebenberg, South Africa in SOCIAL RightS JURISPRUDENCE: EMERGING TRENDS IN INTERNATIONAL AND COMPARATIVE LAW, supra note 137, at 90.

${ }^{303}$ See, e.g., Brown v. Plata, 563 US 493 (2011); Bailey W. Heaps, The Most Adequate Branch: Courts as Competent Prison Reformers, 9 STAN. J. Civ. RTs. \& Civ. LIBERTIES 281, 281 (2013).

${ }^{304}$ See, e.g., Edgewood Indep. Sch. Dist. v. Kirby, 777 S.W.2d 391 (Tex. 1989); Rose v. Council for Better Educ., 790 S.W.2d 186 (Ky. 1989).

${ }^{305}$ See Ctr. Twp. of Marion Cty. v. Coe, 572 N.E.2d 1350, 1354 (Ind. Ct. App. 1991).

${ }^{306}$ See, e.g., S. Burlington Cty. NAACP v. Twp. of Mount Laurel, 456 A.2d 390 (1983). 
and Treatment Action Center, the U.S. court decision of the $20^{\text {th }}$ century with arguably the most historical impact, Brown v. Board of Education, was spurred by civil society pressure and featured a challenging structural injunction that pushed the political branches of government beyond their majoritarian comfort zone. ${ }^{307}$

\section{F. The U.S. Post-Ratification of the ICESCR}

Ratification of the ICESCR will not instantly transform the United States into a social justice paradise, as is demonstrated by both the "progressive realization" language of the ICESCR and the significant gap between the current state of economic and social rights in the U.S. and the terms of the Covenant. ${ }^{308}$ But change will come. It took generations of effort to transform the U.S. Constitution's Bill of Rights into tangible protections for the rights of all human beings to be free from slavery, much less possess the rights to vote, to be free from non-discrimination, or receive a fair trial. ${ }^{309}$ In many of these civil and political arenas within the United States, the struggle continues. ${ }^{310}$ In the context of economic and social rights, determined and creative advocates will need to persuade principled, empathetic judges and lawmakers to translate the ambitious words of the ICESCR into realizable rights for the suffering poor of the United States. ${ }^{311}$

The good news for those advocates is that, post-ratification of the ICESCR, they will have a structure to work with new and powerful tools at their disposal. ${ }^{312}$ Within two years of ratifying the ICESCR, the Unit-

307 See RiCHARD KLUGER, Simple Justice 523-39 (1976) (describing the NAACP's role in pushing U.S. school desegregation litigation and legislative and executive branch resistance to integration).

${ }^{308}$ See KLARE, supra note 260, at 5-6 ("Human rights texts do not build houses, establish schools, or deliver food ... Human rights are normative and discursive resources in struggle, not magic wands.”).

${ }^{309}$ See Amar, supra note 282.

${ }^{310}$ See, e.g., Veasey v. Perry, 135 S. Ct. 9, 12 (2014) (Ginsburg, J., dissenting) (Writing in dissent of the denial of request to stay application of Texas voter identification law, the strictest in the nation, Justice Ginsburg wrote, "The greatest threat to public confidence in elections in this case is the prospect of enforcing a purposefully discriminatory law, one that likely imposes an unconstitutional poll tax and risks denying the right to vote to hundreds of thousands of eligible voters.”).

${ }^{311}$ See Ian Johnstone, Law-Making Through the Operational Activities of International Organizations, 40 GEO. WASH. INT'L L. REV. 87, 105 (2008) (A principle value of human rights treaties is offering a framework for "naming and shaming" violators of the guarantees); Shareen Hertel, Legal Mobilization: A Critical First Step to Addressing Economic and Social Rights, OpenGlobalRights (Nov. 27, 2014), https://www.opendemocracy.net/openglobalrights/shareen-hertel/legal-mobilizationcritical-first-step-to-addressing-economic-and-so (There does not need to be a choice between legal mobilization and grassroots mobilization: "Elite-level legal strategies (connected to People's Union for Civil Liberties in India), moreover, support the harder, grassroots work of expanding popular consciousness and improving service delivery.”).

312 See Beth Simmons, What's Right With Human Rights, 35 DEMOCRACY (Winter, 2015), http://www.democracyjournal.org/35/whats-right-with-human-rights.php ("Trea- 
ed States will be required to submit to the ESCR Committee a report on its current compliance and plans for progressive realization of the rights in the Covenant. ${ }^{313}$ Reports will be due every five years thereafter, and the Committee will pose questions after reviewing each report. ${ }^{314}$ Advocates who have long decried the U.S. record of failing to respect economic and social rights ${ }^{315}$ will have an opportunity to review the state reports and then submit their own assessments to the Committee. ${ }^{316}$ Of course, simply filing reports does not discharge the U.S. obligations under the Covenant. The United States will be expected to show both a plan and tangible steps toward full realization of the promised economic and social rights. ${ }^{317}$

At present, U.S. lawmakers often explain away the neglect of economic and social needs by citing domestic budget constraints. ${ }^{318}$ But that approach is not likely to be successful in the ICESCR review process. In 2007, the ESCR Committee made clear that its analysis of whether a government was using maximum available resources to comply with its obligations would include a process of comparing economic and social rights-related expenditures to expenditures for non-economic and social rights-related areas. ${ }^{319}$ The Committee said it would also compare a treaty party's expenditures in a Covenant-related area, such as education and health, with expenditures in the same area by countries at a comparable level of development. ${ }^{320}$ A U.S. argument of inability to meet its Covenant obligations would likely not stand up well to such scrutiny, given its comparative wealth, low tax burden for high-income

ties change politics — in particular, the domestic politics of the ratifying country ... [t]he most important resource a ratified treaty provides is legitimacy, which in turn can be parlayed into further [domestic] political support.”).

${ }^{313}$ Provisional Rules of Procedure Adopted by the Committee at its Third Session, supra note 159 , at 58.

${ }^{314} \mathrm{Id}$.

315 See, e.g., National Conference of CATHOLIC Bishops, ECONOMIC Justice For All: Pastoral Letter on Catholic Social Teaching and the Economy 43 (1986), http://www.usccb.org/upload/economic_justice_for_all.pdf ("The principle of social solidarity suggests that alleviating poverty will require fundamental changes in social and economic structures that perpetuate glaring inequalities and cut off millions of citizens from full participation in the economic and social life of the nation.”).

316 See AMNESTY INT’L, supra note 161.

${ }^{317}$ International Covenant on Economic, Social and Cultural Rights, supra note 8 at art. 2, ๆ $1-3$.

${ }^{318}$ See, e.g, Nicholas Johnson, Phil Oliff and Erica Williams, An Update on State Budget Cuts: At Least 46 States Have Imposed Cuts That Hurt Vulnerable Residents and the Economy, Center on Budget and Policy Priorities (Feb. 9, 2011), http://www.cbpp.org/cms/?fa=view\&id=1214 ("With tax revenue still declining as a result of the recession and budget reserves largely drained, the vast majority of states have made spending cuts that hurt families and reduce necessary services.”).

${ }^{319}$ Comm. on Economic, Social and Cultural Rights., An Evaluation of the Obligation to Take Steps to the "Maximum of Available Resources" Under An Optional Protocol To The Covenant, U.N. Doc E/C.12/2007/1 (Sept. 21, 2007).

${ }^{320} I d$. 
individuals and corporations, and extensive expenditures on programs like the military. ${ }^{321}$

The Committee is likely to expect the United States to use its significant national resources to promptly honor the obligation to provide its residents with the "minimum core" of economic and social rights, including food, primary health care, shelter and housing, and education. ${ }^{322}$ Advocates will be pushing in the domestic budgeting process for sufficient allocations to address these needs, many of which have gone unmet for millions of Americans for generations. ${ }^{323}$ As noted in Section II above, adjustments to current tax policy will be called for, as will a reduction in the massive U.S. expenditures on the military. ${ }^{324}$

Advocates can also push at multiple levels for direct enforcement of the ICESCR. The Optional Protocol of 2008, which entered into force in 2013, allows for the Committee to employ a quasi-judicial proceeding to receive and review individual complaints of non-compliance with the Covenant. $^{325}$ In addition, it seems inevitable that alleged noncompliance with the ICESCR will be the subject of domestic litigation, coupled with civil society advocacy in multiple forums. ${ }^{326}$ The success of such litigation would be predicated on the resolution of current questions about the existence of a treaty-based private right of action in U.S. courts, a resolution that would recognize that treaties can only be legitimate if they are enforceable, and that the U.S. Constitution's Article VI characterization of treaties as the "supreme law of the land" means what it plainly states. $^{327}$ Courts are likely to entertain requests for economic

${ }^{321}$ See OECD FАствоOK supra notes 5-6 (comparing U.S. social welfare spending in comparison with similar countries); see also Federal Budget Priorities, American Friends Service Committee, http://afsc.org/key-issues/issue/federal-budget-priorities ("Military spending accounts for 57 percent of the U.S. discretionary federal budget. The entrenched culture of militarism, the defense lobby, U.S.-led military interventions across the globe, and the wars in Iraq and Afghanistan have had untold human and financial costs, depleting U.S. resources for human needs.”).

${ }^{322}$ See Comm. on Economic, Social, and Cultural Rights, supra note 165.

${ }^{323}$ See, e.g., Andrew Fieldhouse and Rebecca Thiess, The 'Back to Work' Budget: Analysis of the Congressional Progressive Caucus Budget for Fiscal Year 2014, Econ. \& POLICY INST. (March 13, 2013), http://www.epi.org/publication/back-to-work-budgetanalysis-congressional-progressive/.

${ }^{324}$ See, e.g., Federal Budget Priorities, supra note 321.

${ }^{325}$ Optional Protocol to the International Covenant on Economic, Social and Cultural Rights, supra note 162.

${ }^{326}$ Ayman Sabae, Four Strategic Pathways for the Realization of the Right to Health Through Civil Society Actions: Challenges and Practical Lessons Learned in the Egyptian Context, 16 HeALTH \& HuM. RTs. 104, 115 (2014), http://cdn2.sph.harvard.edu/wpcontent/uploads/sites/13/2014/12/Sabae-final.pdf (efforts to guarantee the right to health to all Egyptians included legislative proposals, public advocacy, coalition building and litigation, with the approaches complementing each other).

${ }^{327}$ See Medellin v. Texas, 552 U.S. 491, 513-14 (2008) (majority of Supreme Court stating that treaties do not create a private right of action in U.S. courts); Oona Hathaway et al., International Law at Home: Enforcing Treaties in U.S. Courts, 37 YALE J. INT'L L. 51, 90-105 (2012) (offering proposals for treaty enforcement in U.S. courts). 
[Vol. 23:1

and social rights structural injunctions, which have been proven in both multi-case studies $^{328}$ and notable individual examples ${ }^{329}$ to have a positive impact on the lives of people struggling to enforce their economic and social rights. Brown v. Board of Education provided the $20^{\text {th }}$ century with its U.S. landmark human rights structural injunction decision. Its $21^{\text {st }}$ century equivalent may look more like the sweeping, lifesaving rulings in People's Union for Civil Liberties and Treatment Action Center.

\section{CONCLUSION}

The United States' charity/justice imbalance is not just an artifact of the nation's history and culture. It is a product of the nation's laws. ${ }^{330}$ As my long-ago Legal Services client struggling with poverty and disability discovered, our wealthy country allows millions of its residents to suffer from inadequate food, shelter, and health care. This suffering is caused in part to an ill-advised provision that is present in the law-the charitable tax deduction, which does not effectively address economic and social needs, forces an inequitable poverty relief and tax burden on the middle class, and lulls the population-including the judge who ruled against my unfortunate client-into a false sense of complacency about its poverty crisis. The suffering is also caused by a notorious hole in U.S. law, the lack of enforceable economic and social rights. The United States can remedy its charity/justice imbalance by removing the charitable tax deduction and replacing it with ratification of the International Covenant on Economic, Social and Cultural Rights. Under this two-part approach, charity would take a step back. Justice would take a step forward.

And yes, judge, there will be a program for people like her.

${ }^{328}$ See Landau, supra at 237-38.

${ }^{329}$ See notes 291-301 (India and South Africa examples of impactful structural injunctions on economic and social rights).

${ }^{330}$ See Klare, supra note 261, at 6. ("Rights, legal practices, and legal outcomes are not autonomous forces organizing social life, but neither are they entirely determined by social structures independent of law. Legal practices can sometimes disrupt the ideological or institutional status quo and unleash transformative dynamics.”) (citation omitted). 